$\mathrm{A}_{4}$

1825 
00028753664

Hollinger Corp. $\mathrm{pH} 8.5$ 


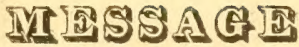

FROX THE

\section{PResident of The United states,}

TRANSMITTING

\section{Copies of a Correspondence, sc.}

\author{
UPON THE SUBJECT OF
}

The Capture and Detention, by British .Armed Vessels,

OF

\section{AMERICAN FISHERMEN,}

DURING THE LAST SEASON.

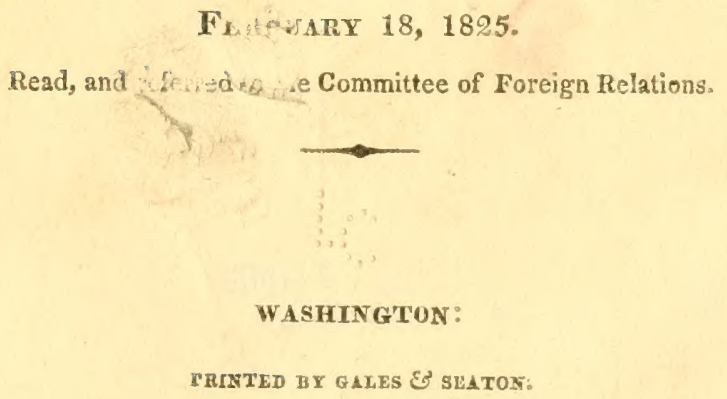

1825. 

Departaent of State,

Washington, Feb. 16, 1825.

The Secretary of State, to whom has been referred a resolution of the House of Representatives, of the 1st instant, requesting the President of the United States to cause to be laid before it such information as might be in his possession, and which, in his opinion, it would be proper to com. municate, touching the capture and detention of American Fishermen, the last season, in the Bay of Fundy, and what progress has been made in obtaining redress; has the honor, respectfully, to submit to the President, copies of the letters and documents in this Office, which contain the information called for by the resolution referred to.

JOHN QUINCY ADAMS。 
4. 


\section{LIST OF PAPERS.}

Mr. Brent to Mr. Addington, September 8, 1824.

ENCLOSURES.

Memorial of Aaron Hayden and others, July 27, 1824.

Affidavit of Robert Small of Elisha Small

do.

of Elias Ficket

do.

do.

Memorial of Hayden, Kilby, and others, August 16, 1824.

$$
\text { of J.G. Faxon }
$$
do.

Protest of Harding, Clark, and others, July 22, 1824.

Affidavit of Charles Tabbuts 23,

Protest of Hubbard, Hantz, and others, 24, of James Woodward, sen. and others, August 7, 1824.

Mr. Brent to Mr. Addington, September 21, 1824.

\section{ENCLOSURES.}

Messrs. Wass and Nash to Mr. Adams, September 6, 1824.

S. Emery for Wilmot Wass, to same do.

Protest of Charles Talbut, and others, September 23, 1824.

Mr. Brent to Mr. Shepley, October 8, 1824.

Mr. Addington to Mr. Adams

5.

\section{ENCLOSURES.}

R. A. Lake to Mr. Addington, September 9, 1824.

Captain Hoare to R. A. Lake, August 26, do.

Same to same, September 2, 1824 .

Same to same, do.

Mr Shepley to Mr. Adams, November 6, 1824.

\section{ENCLOSURES.}

Affidavit of Robert Small, November 5, 1824.

of Paul Johnson

do.

of Hebbert, Hunt, and others, 5th and 6th November, 1824.

of Jones Wass, and John Wright, November 1, 1824 .

of Charles Tabbut and Josiah W. Perry

of Christopher Wass and Jones Wass

of Joel M'Kinsey

of Otis Bryant and Moses Smith

of Jacob Winslow

2 ,

1,

3 ,

3 ,

of Wm. Howard, Benj. Newman, and Thos. Brown, 6, 
Affidavit of Elisha Small and Benjamin Small, November 6, 1824. of B.W. Coggins and Henry Coggins, of Harding Clark, of Wm. Rumery and Robert Rumney $\%$ 6 , Mr. Emery to the Secretary of State, September 27, 1824. Copy Protest, Jones Wass and John Wright, in case of "Rebecca," schooner. Copy. 
$M r$. Brent to $M r$. Addington, dated

September 8 th, 1824.

Sir: I have the honor to transmit to you three memorials from sundry citizens of the United States, belonging to the state of Maine, ac. companied by seven protests and affidavits, which exhibit the nature and extent of the facts referred to by the memorialists, complaining of the interruption which they have experienced during the present season, in their accustomed and lawful employment, of taking and curing fish in the Bay of Fundy, and upon the Grand Banks, by the British armed brig Dotterel, commanded by Captain Hoar, and another vessel, a provincial cutter of New Brunswick, acting under the orders of that officer; and earnestly soliciting the interposition of this Gov. ernment, to procure for them suitable redress. With this view, I was charged by the Secretary, before his late departure from this city, to communicate to you the above papers, and to request your good offices towards obtaining for the sufferers the indemnity to which they appear to be so well entitled, not only from the peculiar nature and extent of the injuries and losses of which they complain, proved and illustrated as they are, by the series of protests and depositions accompanying their memorials, but from the serious violation of the rights and liberties of the citizens of the United States which they in. volve, in the use of the same fisheries; and I have the honor, accordingly, to request that you will have the goodness to make such repre. sentations to the commanding officer of the naval forces of your $\mathbf{G r o}_{\text {- }}$ vernment on that station, or to the Colonial Government of New Brunswick, as may be available, not only for the relief of the memorialists, but for the prevention of similar interruption. in futures

I have the honor to be, with distinguished consideration, sir,

Your obedient and very humble servant,

DANIEL BRENT.

\section{ENCLOSURES.}

Memorial of Aaron Hayden, Kilby, and others, 27 th of July, 1824. Do. of J. G. Faxon.

Do. of Aaron Hayden, John Burgin, and others. 


\section{To the Hon. Johy Quincy ADams,}

\section{Secretary of State for the United States.}

The memorial of the undersigned, merchants and ship owncis, resid: ing at Eastport, in the county of Washington and state of Maine, RESPECTFULIY REPRESENTS:

That your memorialists, during the present year, have invested a larger amount of property in vessels than they have heretofore done, for the purpose of carrying on the business of fishing; that the industry and enterprise of our seamen have been unusually directed to the employment of taking and curing fish, under the encouraging and beneficiai laws of their country; and that, without interruption from a foreign power, their labors would have been crowned with success, and they would have enjoved the fruits of their toil.

But your memorialists have to regret the necessity which compels them to state to the Hon. Secretary their grievances, and requires of them to seek redress, through him, for the many acts of violence and injustice which have been committed by his Britanic Majesty's brig Dotterel, commanded by Capt. Hoar, in total disregarl, and in violation, of the subsisting treaty between the two governments. Your memorialists, premising that the American fishermen in the Bay of Fundy, for these two or three years last past. have been interrupted and taken by British armed vessels, while fishing agreably to the provisions of the treaty, beg leave respectfully to state, that, during the present year, the British armed brig Dotterel has captured nine sail of fishing vessels, and sent some of them into the province of NewBrunswick for adjudication, while others have been converted into tenders, without trial, for the purpose of better molesting our fisher. men. They have insulted and abused the crews, turned them on shore in a foreign country, entirely destitute, and without the means of returning to their homes, and have said, repeatedly, that they would take American fishermen wherever they were to be found, and without regard to the treaty.

'That the brig's barge has come into the wharf at Eastport, and taken and carried away two boats laden with flour.

That the American fishermen have been so molested on the fishing ground in the Bay of Fundy, common to both countries, that they dare not again attempt to avail themselves of the rights and privileges secured to them by treaty, and which are well defined and well un. derstood by every fisherman; and, inasmuch as they are debarred the privilege of making a harbor, for the purposes of shelter, and purchase wood, and procure water, it operates as a deprivation of a great and important benefit, which they feel that they have a right to enjoy without interruption.

That, unless something be done for the protection of our fishermen, your memorialists believe that many vessels of this and the neighboring states will be captured or thrown out of employ, with great injury to private interest, and not without an infringement of public rights.

Reforring the Hon. Secretary, therefore, to the annexed affidavits of the masters of three of the captured vessels, and holding ourselves 
responsible for the truth of the above allegations, your momorialists respectiully reguest that some prompt and rifichent measures anay be adopted by our Government, to protect us in our rights and pussuts, and that our fistremen bay not bo molestent, mor oin shores invated with impunity by the subjects of any toreign power:

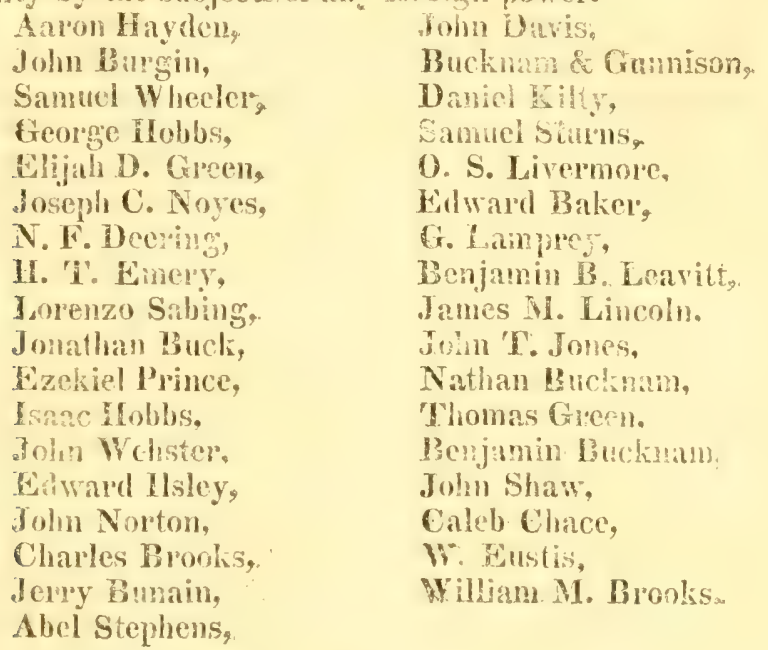

July $\approx \%, 1824$.

Easteort, July 27 th, 1804.

I, Robert Small, master of the schooner Reintecr. of Luber, do iestify, declare, and say. that I sailed from Jubec, in the state of Maine, in the above schooner, on the $29 d$ day of Inly. 1824. on a fisl:ing voyage in the 3ay of Fundy. On Scinday the 2.5th suly, finding our water very bad, went into a harbor in an uninhabited place cal. led . Two Istands," near. Grand Mcsan. for the purpose of procuras a fresh supply of wood and wates. That we pickel up abont one cord of sift wood from off the bcach of said island, aml filled twe barrels of water lrom: a spring or loronk on said island. And on Monday morning following, about 4 o'clock, got unifer weigh and towed nut of the harbor-it being calm; and hilhen from one to two miles from the shone, we were brarded by a barge from tha Bbritish man of war brig Dotterel, containing nime men. with arms fre con. manded by an onticer from said brig, of the name of Jones. Who togk possession of my ressel and papers, and brotight her to anchor; me. nacing myself and crew with viulence; theatening our lives, de, They then took out all our crew, with the exception of myself, put them on board the schooner Friend, Cogrgins of Luber, which resel they also captured, and made a cartel of, as they fermed it; manned my ressel, and ordered her for St. Ardrew's, New Brunswick.

While on our voyage, we had caught no fich within from six to 
cighteen miles from shore. We hall uo goods or merchandise on board, nor did we go into a harbor for any other purpose than to procure woud and water.

ROBERT SMALL.

\section{$\left.\begin{array}{l}\text { State of Maine, } \\ \text { Washington. }\end{array}\right\}$ ss.}

Then personally appearcd, the said Robprt Small, and made solemu oath, that the forcgoing statement, by him subscribed, was true, before me,

\section{FREDERICK HOBBS, Justice of the Peace.}

EAstront, July 27, 1824.

I, Elisha Simall, of Lubeck, Maine, on oath declare and say, that, on the seventh of July inst. I Icft Lubeck as master of the srhooner Ruby, on a fishing voyage in the Bay of Fundy, and on the 25th July, bring nearly destitute of wood and water, we made for the outer islands Jying neal Grand Menan, and finding the sea so heavy that we could not land, we went into the harbor of the "T'wo Islands," so called, to get a supnly. We got in there between three and four o'clock, P. N.; when 1 sent my boat and seven hands to fill water, and get wood. We got one buat load of drift wool, and filled four barrels of water, when day-light sint in, and we had not time to get more. The wind died away calm, and we could not get out of the larbor again that night. The next mopning we got under. weigh with a very limht wind, aud got out of the harbor, and it died away calm again. Tre were then boarded by a barge belonging to the British armed bis Dotterel, commandird by an ofices of said brig by the mane of Jones, and having on board nine men, armed with guns, cullasses, dirks, and pistols. Jones demanded my papers which I delivered up, and ordored ny crew lopward-told his men to go down and search the ressel: they fonnd nothing but Bish, and salt, and fishing gear. Ife then told my rrew to take dheir dunnare, ordered them on board the fishing schoner Diligent, which had previously been taken, and sent Captain Ficket, of the Diligent, to Lubeck with the men. We had no merchandise on board the said schooner Ruby; had not caught a fish, or attempted to catch one, within five miles from the shore, nor had we been into any harbor, until the ome above named.

ELISHA SMALL.

\section{$\left.\begin{array}{c}\text { State of Maine, } \\ \text { Washington, }\end{array}\right\}$ ss.}

Then personally appeared the said Elisha Small, and made oath that the foregoing statement. by him subscribed, was true,

Before me,

FREDERICK HOBBS, Justice of the Peace. 
EAstport, July 27th, 1824.

I. Elias Ficket, master of the schooner Diligent, of IIarrington" Maine, do testify, declare, and say: 'That, on the sixteenth of July, eighteen hundred and twenty-four, I left Eastjort, Maine, in the above schooner, for a fishing voyage, in the Bay of Fundy; that. on Sunday, the twenty-fifth of July, being nearly destitute of water, we repaired to a place called "Two Islands," lying to the southward of Grand Menan, about three fourths of a mile, and on which there are no inhabitants, and procured two barrels of water from a spering or brook on said island. On Monday morning, got under weigh, and the wind being light, towed out of the harbur'; and when about one and a half miles fiom the shore, while attempting to get on the fishing ground, (which is six to nine miles from any shore) we were boarded by a barge from the British man of war brig botterel, commanded by a sailing master, whose name was Jones, and having on board nine men-taken possession of, and ordered to receive on board the crew of the schooncr Ruby, of Lubeck, which vessel they hat previously captured, and to sail immediately to Lubeck, as a cartel-there. by interrupting us in our lawful cmployment. and destruying our fishery. I further declare, that we had no goods or merchandise on board our schooner; that we did not go into a harbor for any othes purpose than to obtain a supply of water.

We were not fishing where we were captured, nor had we attempted to catch fish within more than six miles from the shore, while on our voyage. I further declare, that we were badly used by the barme's officers-threatening to shoot us, \&c. \&c. And they said their orders were tocapture all Americans they met with, right or wrougthat there was no treaty-and that Americaus should not fish in British waters.

\section{State of Maine, ? Washington, ss. $\}$}

ELIAS FICKE'T.

Then personally appeared the said Elias Ficket, and made solemn oath, that the foregoing statement by him subscribed, was true, before me,

FREDERICK HOBBS.

Justice of the Peace.

To the Hon. John Q. Apars,

\section{Secretary of State:}

The undersigned, inhaibitants of the county of Washington, in the state of Maine, interested in the fisheries in the Bay of Fundy, beg leave to represent:

That, although till the present year, the privileges reserved and confirmed to American fishermen by the convention of 18is, have 
been enjoyed with but fow interruptions, they are now, in a great measure, cut off and prostrated. by the piratical conduct of the commander of his Britanic Majesty's brig Iotterel, and the oflicers under flis command, aided by the provincial Cutter attached to the port of St. Andrew's.

That the oflice having the clatege of the armed boats ordered to cruise round Grand Mcuan and Campo Bello, has written instruc. tions, which have been eshibited to our citizens, from the commandes. of the Dotterel, to seize. and send into St. Andrew's, all Ameriens fishermen found within three marine miles of said Islands. 'That, under these orders, that ollices, "ithout any pretence other than cuch instructions, has seized the following vessels:

Schooner Pilgrim, of Lubec, Woodward, master;
66 Hero, of Denneysville. Clark, "6
of Rebecca, of Addison, Wass,
6r Galeon, of Lubec, Hunt,
66 William, of Addison, Tabbuts, "6
of Ruby, of Lubec, E. Small,
6\% Irein Deer, of Lubec, R. Small, "6

The Pilgrim and the Hero were captured while under'sail, stani ing for Lubec in distress, and more than three miles from said Grand Menan. Aud, although this capture took place on the sixternth day of June last, said schooner. Ilero has not been sent in for trial, but has been armed, and is still used as a tender to saill Brig Dotterel, the more easily to decoy other fislsing vesscls. The Rebeca went into Grand Menan in distress for wood and water, and, having obtained a supply, was preparing to return to the fishing ground, when she was taken. The Graleon, with seventy quintals of fish on board, went in for the same purpose, and, within a few minutes after she bad accom. phished her object, it being quite late in the evening, and the fog extremely dense, she was taken, and sent to St. Andrew's. 'TheWilliam, with one hundred and twenty quintals of fish on board, left the fish. ing ground in clistress for want of water, and had come to anchor npar the shore of Grand Menan: her sails were not handed, nor was her boat lanuched liom the deck togo on shore, when she was seized and taken to St. Andrew's. 'The Ruby and Reindeer went in to Two Island liarbor for wood and watcr, near Grand Menan, and were immediately seized.

We beg leave here to observe, that American fishermen have no accasion $\mathrm{nor}$ inducement to violate the provisions of the aforesaid courention; nor have they, as we firnly believe, in any instance, given just cause for complaint.

The protest of the master and crew of the Galeon, has alrealy been forwarded you. Those of the Hero and Higrim will accompany this memorial, and will, we trust, establish the facts relative to the wanton detention of those vessels, as well as shew the indignities cast upon the American flag, and the insults offered the ciazens of the Luited States by the British oflicers of the Dotterel and Mrovincial Cutter. 
To clain these vessels in the Vice Admiralty courts in New Prunswick, would be worse than a total loss: for, besides, the fact that the claimant must give bouds to the amount of \pm 60 , currency of New brimswick, to pay costs of libed, whether condemnation takes Mace or not, his ressel, shoub! he preval in a claim, (proverbially hopeless) will come to his hands in a dismantled and ruinons state. Yo care is taken of American vessels seized for a pretended violation uf Brilish reschue laws: for, as tiry can never sail under British paprea, but must be broken up or taken from the country, the seizung wticer has no inducement to keep them in grood repait. with the exinctation oi being remuerated ror particular attestion by a more ad-

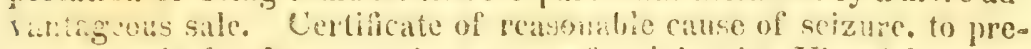
vot a sut for lamages, is nerer relised by the Vice Armiralty Intgro of New Brunserick, to a Britioh maval uflicer, when the pro. "er application is made. Wo appreal, theretore, to the Provinciag vinuts for redress would be worte than unavailing. It would only aggravate the damages already sustained.

'T'o the successiul advocate of the rights of American fishermen, if need not be urged, that this state of things is preculianly vexatious and suinous. To the owners and crews of the ressels detained, and to their famiiies, it is, in many instances, oppressive and distressing whid tiscy ate left without redress, unless their own Government in. terpose. 'To that Gevernmetit they appeal; and they do it with fulf contidence that their complaints will be heard, and their wrongs gesivessed.

Ingust 16, 1824.

Sol. 'Thayer'

llayden and Killey

Jolin Norton d C O.

Jolın A. Baskum

Benj. Bucknam

Ethel Olmstead

Jolun Welister

A. Barnard

Oliver \& James Giover

Daniel Young

Daniel Pease

William H. 'Tyler

Joseph Whitucy

A. P. Mills

Joshua Gibbs

Samuel Miar's

J. Boynton

George \& Isaác Hobbs

Samuel Wheeler

Green \& Shaw

WV. Eustis

\author{
Darius Pearn \\ Buck \& Tinkham \\ Renj. B. Leawell \\ James M. Lincoln \\ Bucknan \& Gunnison \\ John G. Faxon \\ Joseph Sumner \\ Davenport Tucker \\ Jeremiah Fowler \\ Moses Fuller \\ F. A. \& 0. Burrall \\ Calvin Gibbs \\ Darms \& Noyes \\ William M. Brooks \\ Samuel B. Wadsworth \\ 'I'. Pilsbury \\ Johu Faxon \\ William Wass \\ William Nash \\ Jery Bevan \\ Lewis Putnam.
}




\section{To the Honoraule John Q. Adlams, Secretary of Statc to the United Stutes.}

The memorial of Joln Gardiner Faxon. merchant, of Lubeck, in the state of Maine, humbly sheweth:

Thint the said Jolm G. Faxon is sole ownel of the schooner called the Galcon, of said Lubeck. That said schooner being on a fishing voyage, in the Bay of Fundy, was seized and detained by part of the veicers and crew of the british armed brig Dotterl, and is still detaned, in the bivish port of Sant Andrew's, by the authority of the commander of said brig, merer the circumstances set forth in the protest ammexed; which seizure and detention is to the greal damage of the satd John G. Faxon: wherefore, your memorialist humbly prays, that the lomorable Secretary will cause such proceedings relative to the premises as he may think proper, to relieve the said owner and crew of the said schooner Galeon; and your memorialist will ever pray, \&e.

And your memorialist further states, that the just value of the schooner Galeon, with her cargo and equipments, at the time of hel capture and detention as aloresaid, was lifteen hundred dollars.

JOHN G. FAXUN.

$\left.\begin{array}{l}\text { Uniten States of Amenica, } \\ \text { State of Mlaine, W'ashington, }\end{array}\right\}$ ss.

Be it known to all fowhom these presents may come: That, on this twenty-second day of Jnly. in the year of our Lord one thousand eight itundred and twenty-four, before me, Solomon Thayer, Notary P'ublic, hy legal authority dinly commissioned and sworn, and dwelling ar Lubec, comty and state adoresaid, personally appeared, Hardiris Chark, master of the pink sterned schooner Hero, of Dennysvillo fophaim Clark and William H. N. Brown, fishermen on board saiel echomed, who, being severally sworn, do depose, declare, and saty: 'Tasat, on the elerenth day of' June, now last past, they sailed from Dennysville in said schooner Hero, fitted for a fishing cruize of six weeks, and arvived on Monday morning, being the fourteenth day of sail suze, on the fisting ground called the Grand Menan Banks, frobia nine to twelve marine miles from land, and commenced fishing. 'That they rsintinned to fish till Wodnesuay the sixteenth day of said momth, Wlien the schooner struck adrift. It was then about nine c'clock. A. M. Got under weigh immediately, and attempted to regain thr fohing gromul, but could not effect it by reason of a strong

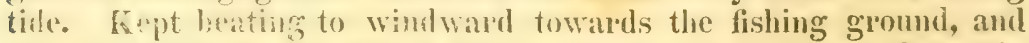
the tirle slarkinm, sat within about half a mile of it, and from six to nine miles form any land. when an armed boat, sail to belong to the British arned brig botterel, fired two muskets, loaded with balls, 
across said schooner Hiero. She was rounded to, and an oflicel came on hoard and took forcible postession of the resspl and her paper's.

The declarants liuther depose ant say, that they were kept sometimes on hoapd said schonnel' sometimes on boand the Dotterel, oi some of her boats, from that time till the twenty-ninth day of said $J$ Juc; and were allowed for a part of this time only one meal per day. 'That they were every night in harbor' and near home; but though they earuestly solicited to be set on shore, it was not granted them, but were forecel by threats and menaces that they wouk be cut in preces in case of refusal to do the same cluty as the common British sailors. They were at last landed at St. John, a distance of eighty miles from Denmssille, an! eren subjected to great expense and distress in getting liome.

The declarants further say, that said schooner Hero has been maned and armed, and is still made use of as a tender for said brig Ibotterel and bas never becu libelled or sent in for trial. And the

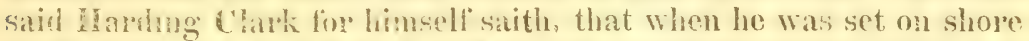
at St. John, his pocket-ibok and private papers were taken fiom him and retained.

Wherefore they do protest, an! I, the said Notary, in their behall, do solembly protest aganst the winds, seas, tides, armed boats, pirates, the vantm and flagrant abnse of power, and whatsoever else that caused the seizule and defention of said schooner Hern, and for all damages, costs, winl expenses sustained, and to be sustained, by reason of such illegal aml wanton detention of said schooner as alowesaid: and I. the satid Fintary, do arer that the same was caused, not by a breach of the revende laws of Great bitain and the Cinted States respecting the fisheries, done. made. or committed, by said schonner Inop; but was wholly without any fant on the part of sail schooner, or any person therest, but an act of piracy committed on the high seas without at pretence of authority.

In fith whereof. I, the said Notary, have hereunto set my hand amd anixed my seal of oflice, the rlay and year first above written.

SOLOMON THAYER, Notary Public.

HARDING CLARK.

WILTIAM H. N. BROWN.

EPHRAIM CLARK.

\section{UNITED STATES.}

\section{$\left.\begin{array}{l}\text { State oe Matine, } \\ \text { Fashiugton, }\end{array}\right\}$ ss.}

To all whom it may or doth concern, know ye, that, on the twenty third day of July, in the year of our Lord eighteen hundred and twenty fum, before me, Solomon Thayer, Notary Public. by legal authority, duly appointed, commissioned and sworn, and dwelling in 
Luber, state and county aforesaid, personally appeared Charles 'Tabbut, master' of the fishing schonner William, of Addison. and noted his protest; and now, on the twenty third day of August, Anno Domini cighteen hundred and twenty four. he again appear's to extend the sume, and with him, also, apjear Thomas Wright Benjamin Jepynokds, and Josiah W. Perry, fistrermen belonging to said schooner William, who being severally sworn, do declare and say:

'That, w the first day of July, now last past. they sailed in said schooner Willian, on a fishing cruaze in the bay of Fundy, and anchored between what is called Mur-ground and the Grand Menan Bablis, a distance from niuc to fifteen miles from land: that they contimsed there at anchor, and fishing till the fouriechth day of said July, when, having only filteen gallons of water on board, and that muth fin use, it was thought prudent and necessary to deun into Gull Cove, Grand Meman. an! obtain a supply. Arrived at Gull Cove on the fiftenth of said July, at two P. Ne. and came to awchor. the fog beingextremely dense. 'The sails of the William were not handed. as it was intended to obtain water with all possible dispatch, and return to the fishing ground. 'Phey had gone below, and were tak. ing dinner, and not more than ten minutes from the time of anchoring, the boat wot having been lannched from the deck to go on shore, when they were boarded by an armed laurch. commanded by one Jones, an officer of the English gron brig Dotterel, who demanded their business-their papers, and tonk forcible possession of the rese sel. Jones sent his linen beko: to examine the water casks, and ascertain what quantity of water there was on board the William. They reported there were three hall casks of water below, one empty barrel, and one with the hoops off. Mir. Jones was then told by these declarants that the report of his men was incorrect; that one barrel only had any water in it, and that but fiften gallons, completely mfit for use; that, besides this, there was a hall barrel of molasses. and a barsel with five or six gallons oi beer. Mr. Jones ordered the Bitlian nuder weigh-took her in nearer the shore-moored her in a dangerous place and stripied her, and took the William's boat, carried it on shore, and gave out word that if any of the Willian's crew attempted to go on shorr, or if any boat was called along side, or. if he heard any urise on board, he would shoot them. They were thus left till near sui-set. Without a drop of water fit to drink, though they frequently hailed Mr. Jones as he passed and repassed, and stated to him their distress, and begged for water" their prayer was wholly disiegarded. About sun-setting, a vessel from Campo Bello anchored along side, and by permission of the captain thereof, they ubtained from the shore a two gallon keg filled with water.

'Ihese declatants further' say, that, when Mr. Jones became satisfied there was no water fit for use on board the William, in a violent rage, he said "the American fishermen had been damned saucy to the inliabitants on Grand Menan." The master of the William, one of these declarants, replied that such an allegation did not apply to his vessel; that he had always used the inhabitants as he wished to be 
treated himself. Jones then said "it was damned well for him lie had done so, for otherwise he should have confined him to the deck, ald cut him into ounce pieces." 'To this the master of the Wiiliam replied he should not give himself any uneasiness on that accomnt. Jones, with an oath, irplied to this. "dam you 1 will contine you to the deck, and lash a pump brake across your molth."

The declarants further say. that, on the uext day, the William was got under weigh, and taken to st. Andrews and stripped; that sho had over one humlred and twenty quintals of fish on board when she was captured. Wherefore they do protest, and I, the said sotary, in their behalf, do solemuly protest against said fonrs, and the armed men under his comman, as ainst pirates and piratical scizures and detentions of American fishermen, and whatsoever else caused the forcible detertion of satd schoner William, and lor all expenses, costs, charges, and damages paid or sustained, or to be paid or sustained by reason of said detention. And I, the said Notary, do solemnly aver and declare, that said detention was not by reason of any breach of the revenue laws of Grat Britain, or of the province of New Brurewick, done of committ d by said schoner Wilhan or any one on board thereof? but an unauthorized, a wanton, a piratical act of the said Jones and his abettors.

\section{CHARLES 'TABBL'T, BENJAMIN REYNOLDS, JOSLAH W. PERRY, 'THOMAS WRIGH'.}

In faith whereof, I have hereunto affixed my seal of office. this twenty-third day of August, Anno Domius eighteen hundred and twenty-four.

\section{United States of America.}

\section{$\left.\begin{array}{c}\text { State of Maine, } \\ \text { Washington, }\end{array}\right\}$ ss.}

Be it known to all to whom these presents may come, that, on this twenty-fourth day of July, in the year of our Lord one thousand cight handred and twenty-four. before me, Solomon 'l 'hayer, Notary Public, by legal authority duly commissioned and sworn, and residing at Lubec, state and county aforesaid, personally appeared Hubbard Hunt, junior, mate of the schooner Galeon, of Lubec, Nehemiah Snall, Daniel Jay, jun. John Llunt, and Edwin Llunt, sharesmen, belonging to said schooner, who, being severally sworn, do depose and say. that, on the first day of July, now current, they sailed in the said schooner from Lubec on a fishing cruize to the Grand Menan Banks. On their way thither, and while doubling round the southerly end of Grand Menan, distant about six miles, with their color's at mast-head. they were fired into by the St. Andrews' Cutter, McMaster commander, and ordered to come under said Cutter's lec. 
Mr. Baxter, an oficcr of said Cutter', came on board and demanded her papers, sent his usen into the lond to search her, and went himself for the same purpose into the cabin. After detaining the Gateon about half an hour, she was permitted to proceed. Arrived on the banks the same day, and commenced fishing; on the fifternth day of saici month. having only five gallons of water on board, and wo wood, run in for Grand Menan to gret a supply. Arrived at Beal's passage about half past seven $\boldsymbol{P}$. M. fog quite thick; went on shore and got two barels of water, and a boat load of woud, by permission of Charles 13humorten the owner; it was then abont nine o"clock of the same erening. Having got supper, and intenting to get und:e weigh, as soon as the land tharks could be discerned, to return to the banks, they were boarded by an aned boat bongring to the Whghish brig Dotterell, and their pagers deunden and talicu. The iessel was immediately sot under weigh by order of $\mathrm{Mr}$. Joness. the conmander of the armeal boat, and run into Gull Corr. 'Tlse next day the Galeon was taken to St. Andrews, stripped, and made last in the King's dock.

Whe declarants further depose and say, that, from the time they Jeft Lubec on the first day of sad Juyy, wutil they tun in in cistress, for want of wond and wates, on the evening of the fifieenth of said month, they had nerer been withon there matrine miles of Grand Melisti, nol' caught, ol attempted to catch, any fish within from ten to twenty miles thereof. That, aiter they were taken. the onlicer, Mi. Jones, positively fromised them that he would release the Gialeon as soon as she arrived at St. Audrews; and it was their reliance on his promise, and the belief he could not be so wanton as to add insult to injury, but that he wonld redeem his word, that they have not protested before. She is still retained. Wherefore, they now protest, and I, the said Notary, in their behalf, do solemnly protest against the flagrant abuse of law, (and the right granted to American fichermen by treaty, by armed boats under the British lage, withont a pretenco of authority: against pirates, the wints, seas, and whatsoever clse may have been the canse oil the capture and detention of the Galeon; and $\mathbb{I}$ do ave:, that the capture, and detention, was not by reason of a violation of any revenue law of Great Britain, or an infraction of any privileges granted by the convention, done, or committed by said (ialeon, na any of her crew, but was done withont a pretence of right, and substantially an act of piracy.

\section{HUBBARD HUNT, Jun. NEHEMIAH SMALL, DANIEL TAYLOR, JUn. JOHN HUN'T, EDIVIN HUNT.}

In faith wherenf I, the snid Notary, have hepeunto set my hand and scal of ollice, the day and year first above written. 


\section{United States of America.}

\section{$\left.\begin{array}{c}\text { State of Maine, } \\ \text { Washington. }\end{array}\right\}$ ss.}

To all to whom this public instrument of protest may cone, be it known, that, on the twenty second ray of dune, now bast past. before me, Snlonon Thayer, Notary l'ublic, by legal anthority duly commissioned and sworn, and dwebling at Eubec county, aisd state aforesaid, personally apparted, James Woodward, master of the fishing schooner l'ilgrim, of Lubec, and noted his juotest; and now, on this seventh day of Angust, in the year of our Lord one thousand eight hunded and twenty four, he again appeats, and with him, also appear dacob Winshow and Jataes Woodwart. jr. fiskermen, who being serreally sworn, do dejuste declare, and say, that, on the eighth day of Jute aturestid. they saited firom Lubec on a fishing voyage to the Grand Menan Bank, so cablet: but owing to thick weather and hend winds. did not get on the finturng ground till Mondity the fourtenth day of said June. 'They then came to anchor (the wind blowing quite fresh and a high sea) trefre miles from any land. At four l'. H. of the sature day. they fomel the ressel driting, hauled in the cable, and found the andhor isele ciese to the stock. Made sail and grot on to another part of the fishing genund, nine mileg from land and thes continucd to fish till if cduestay the sixteenth day of said June, but funding their only remaining anchor toro light to hold the ressel in so strung a current, weighed it and stoud for Jubec to obtain a new

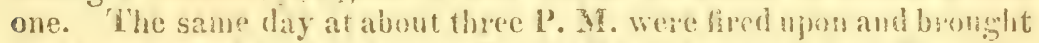
to by an armed boat belongiaghto the English arined brign bu: terel, who took their papers, and ordered Jacob ninslow and Benjanin Scott, fistermer, on boand the tender, putting one seanan and one marine on board the l'ilgrin. 'This was done white the l'ilgrim was under weigh, and from four to six miles from lant. 'The seamen in the bilgrim were ordered to follow the tender, which then steered east, and still linther firom land, and took forcibie possession of the American schooner Hero, Harding Clark, master, also mutcre sail and standing for Lubec. Botin vessels were then taken into Elangron:; Cove, Grand Nenan, and anchored. On Thursday the seventeenth of: said June, asked permission to be set on shore, bit were denited. On the 18th, got under weigh, and stond for the Woll ishand at $6 \mathrm{I}$. M. both vessels were ordered to freave to, and the bilgrims boat to be sent on board the tender. Who ollicer then commiled one of these declarants, James Woodward. ji. only seventech years of age, to row the boat alone cross-latuded, a distance of not kess lian four miles, to board vessels lying at the easter!y part of the Wolf Lwand, and then to row back agaia to the tender. Gn the oflicer's deturn to the tender, he ordered the l'ilgrim to stand in for the Lastern Wulf Island; and these declarants were crmbel!ced to row her (it being then a dead calm) for four miles to gain said place, where she was anchored for the night. Ont the 19 th, at 8 A. M. got under weigh and stood 
to Beaver Liarbor, and came to anchor: were then forced to unbend the sails of the Pilgyim and stuw them below. (On the 20 th, at $8 \mathrm{~A}$. M. were ordered to bend the sails and get under weigh: which was done; and after beating with the wind SSE. and a flond tide for three hours, were ordered back to Peaver Harbor. On the 21 st at $6 \mathrm{~A}$. M. were ordered to get under weigh-beat all day against a strong head wind, and at night anchored in Mason's Bay.

At one o'clock the rext morning, these declarants, knowing that the Pilgrim had violated no law, nor any treaty or convention between the United States and Great Britain, and that they were detained without the pretence of authority on the part of the oflicer of the armed boat, got said Pilga im nuder weigh vithout orders, and stood for Lubec, where they arrived on the said twenty-second day of June, with the Joss of boat, papers, a fowling piece, a pistol. and a great guantity of powder and shot, which were plundered from them by said armed boat.

Wherefore, they do protest, and I, the said Notary, in their behalf, do solemnly protest against said armed boat and the oflicer and men on board thereof-Cagainst pirates and unlawful captures on the high seas-against winds. tides. and whatsoever else. caused the detention of said schooner Pilgrim, and the loss of her papers, boat, dc. and I, the said Notary, do aven, that it was not by reason of a viola. tion of any revenue law of Great Britain, committeil by said schooner P'ilgrim, or any of her crew, but a wanton insult upon the Aner. ican flag on the high seas, without a shadow of excuse, by an vflice: of the British navy.

\section{JAMES WOODWARD, Senr. JACOB WINSLOW, JAMES WOODWARD, Jr.}

In faith whereof, I have herennto set my hand and aftixed my seal of office, this seventh day of August, in the year of our Lordone thousand eight hundred and twenty four.

$$
\text { SOLOMON THAYER, [L. s.] }
$$

Notary Public.

\section{Mr. Brent to Mr. Addinglon, dated}

\section{1st September, 1824.}

SrR: I have the lonor to transmit to you copies of some auditional papers which have been received at this oflice, upon the subject of the interuption, likewise given by the sanc armed British Brig Dotierel, to vessels of the United States employed in the prosecution of the fishery in the Bay of Passamaquodly, and elsewhere in the same neighborhood, as particularly cxemplified in the cases of the two schooner's, Wilniam and Rebecca, which are fully stated in the enclosures, 
and to pray the interposition of your good offices in behalf also of the owners of these ressels, towards obtaining for them the indemnity to which they may be justly entitled.

1 have the honor to be, with high consideration, Sir, your obedient and humble servant, DANIEL BRENT.

\section{STATE OF MAINE,}

County of Hashington, Columbia,

To the Hon. Jonn Q. ADams,

SEPTEMBER 6th, 1824.

Secretary of the Department of State.

Srre: Enclesed is a protest on account of the capture of the fishing Schooner William of Addison in the county aforesaid, belonging to, and owned by. the subscribers, citizens of the United States. These papers are enclosed for the purpose of procuring redress for the injury and loss sutained. The said Schooner William was 41 tons burthen, and but four years old, with a new suit of sails and rigging, cables, anchor's \&c. valued at 120 Quintals fish on board at \$s per Quintal Bounty for said schooner Damages in consequence of said capture - $\quad-\quad 50000$

$\$ 2.02262$

All requisite evidence, should further be needed, will be furnished; and the subscribers pray that such measures may be adopted, as shall lead to a redress for the loss and danage by them sustained.

\section{WILLIAM WASS, WILLIAM NASH.}

\section{State of Mane, Counte of Wasiningtos,}

Columbia, September 6, 1824.

SrR: The unjustifiable scizure and confiscation of certain fishing ressels in the water's of l'assamaquoddy Bay, it is hoped, will deserve and receive the attention of Govermment. Enclosed is a protest against the fapture of the schooner Rebeca, of Addison, in the comn- 
ty aforesaid. the property of Wilmot Wass, of the said Addison, a citizen of the Cuited States.

'The schooner' Rebecca, valued at $\$ 60000$

25 quintals fish, at $\$ 3 \quad 7500$

Bounty 9450

Damage in conseruence of captul'c 300 '00

$\$ 1,06950$

In hhall of the said Vase, I have to rexue that such measnres may he adopted a'; wili lead to redrests of the loss and injury sustained by lim.

To the Iron. Joun Q. Ansms,

STEPIIN EMERY for

WIEMOT WASS.

Secretary of the Department of Siate.

Charles Tabbuts, master of the schnoner Villiam. of Aldison, on oath, deposeth and saith, that he sailed on board said schoomer, on a fishing cruise. wil the 1 st day of July, 18\%; anchored hetween what is called the Grand Menan Banks and the Murr.gromb; continued at anchor and fishing till the 14 th of July, when, having on board only diften gallons of water, and that unfit for use, it was determined best 10 run into Cull-cove, and obtain a barel of water: arrived there on the 1.5 th about 2 P. M. and came to anchor: the fog very thich; did mot hand the sails, as we intended to get the " ater on board and go back. While below, and taking dimer, and not mone than ten inimutes frum the time of anchoring, our boat still on deck. we were: boarded by a Mr. Iones, an officer of the Dotterel, nur papers demanned, and taken into his possession. If clemanded onr peasons for being there, and was told them. He sent lis men below, to see how much water we lad; they reported that there were three and a late barrels of water below, one empty barel, and one with the hoops off. Mr. Jones was then told by me, that lhere was no casis but one that had any watem in it, and that lial only filtern mallons, and so bad it could not he used; that there 1 as one-half bartel of molasses, and a barrel with five or six gallons of ber:. Mr. Somes ordered the William under weigh; took her in towards the shore: moored her in a dangerous place, and stripped her; touk the boat and carried her on shore, and gave orders that if ally of the billian's crew went on shore. or asy boat was called alomig sid", or if he heard any noise on board, he would shoot us. We were thes left witlont a cimply of wa-

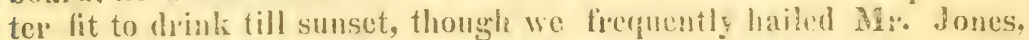
and stated nur distress, as he passed us-we weie wholly disregardcd. About sumset, a ressel from Campo Bello anchored alomsiste. and, by permission of the master. the deponent went on shore and got a two gallon keg of water. Gn the 16 th instant the Willian was got under weigh by Mr. Jones, and taken to St. Andrews. 
The deponent further saith, that, when Mr. Jones found tiese was no water on board fit for use, that, in a violent rage, he tuld this deponent that the Ainerican fishermen had been damned satey to the inhabitants. The deponent replied that he had not been saucy to the inhabitants, but had always used them as he wished to be used himseif. Jones replied that it was damned well for me that I had been so, or he would otherwise confine me to the deck, and cut ine into ounce pieces. I told him that I should not give myself any uneasiness on that account. Then. with an oath, he said, damn you, I will confine you to the deck, and lash a pump-brake across your mouth.

CHARLES TABBUTS.

\section{$\left.\begin{array}{c}\text { State of Maine, } \\ \text { W } \\ \text { usfington, }\end{array}\right\}$ ss.}

On this $23 d$ day of July, 1824, personally appeared before the Charles 'Tabuts, and made solemn oath to the truth of the foregoing statement by him subscribed.

SOLOMON THAYER,

J. P. S. Not. Pub.

Mr. Brent to MY. Shepley, Attorney U. S. for District of aIine.

\section{Department of State,}

\section{Washington, October 8th, 1824.}

SIr: In the absence of the Secretary, I have the honor to transmit to you the enclosed copy of at Irtter from inr. Addington, the British Chargé d'Afraires, at this place, in answer to remonstrances from this Department, upon the complaints which were lately exhihired to it, by sundry citizens of the Cnited states lesidine in the state of Maine, and engaged in the Fisheries. against the commander of the British armed brig Dotterel. for interuntions and other injuries which they state to have experienced, at the instance, and under the orders of that oflicer, in the prosecution of their accustomed employurent during the present season and requesting his gool oflices towards obtaining for them the redress to which they may be entitled; and I beg leave, at the same time, to trouble you with copies of the letter's and documents referred to, and enclosed in, Mr. Adlington's letter, which exhihit serious complaints on the part of the British authorities, against all, or very many of the same individuals, in refe:ence to the subject-matter of their own complaints. I do this, with the request that, as som as convenient, you would have the goodness to institute an inquiry into the circumstances particulary complained of by the British Chargé d'Affaires, and communicate the result to this Department, that the 
Secretay may be cnabled, with the adrantage of the counter-statement to be thus expected, as I doubt not he will, to give Mr. Addington satisfartory cxplanations in relation to the transactions complaincol of by him; of otherwise, to direct such procedings to be had, as the circumstances of the whole case shall render alvisable and proper.

I am, with great respect, Sir, your obedient and humble scriant, DANIEL BRENT.

\author{
Mr. Adlington to Mr. Adums.
}

Wasurgtos, October 5 th, 1824.

Srm: Ilave the honos to acknowledge the receipt of two letters, one dated the 8th, and the other the 21st ultimo. which Mr. Brent addressed to me, in pursuance of instructions from you, relatively to rertain American fishing vessels averred to have been detained, in violation of the terms of the convention of 1818 , by His Riajesty's sInop Dotterel, in the Bay of Fundy, in the montlss of June and July last.

I shall not fail to communicate, without lose of time, the whole of the papers relative to this matter, to the Admiral commanding II is Majesty's naval forces at Halifax; and in so doing shall strongly recommend that a full and impartial inrestigation be made into the merits of the various cases therein reporterl; the result of which shall be forthwith inparted to you whenever it conces to my knowledge.

Mean time, sir, I must inform you that a repurt of those very occurrences, of at nature very different from that made by the indiviluals to you, has reached me from Rear-Admiral Lake, of whose letter. together with its enclosures, I have the honor to transmit to you copies herewith.

It is therein made to apprear, that the fishing resscls above-mentioned weredetained by the Dotterel solely on account of their having becrs detected in the commission of a direct infraction of the treaties existing beiween the two nations, having, in fact, been found pursuing there orcupation withont the bondaries assigned to them by the term: of the convention of 1818.

(In this point, however, the parties are at issue, each stating his case according to his swe view of it. Thus fat, therefore, there is ground for a candid and impartial investigation on both sides. Such I have tecommented to Admial lake. and such, I trust, you will also canse to be instituted here.

But there is another point. sin, on which I lament that there should in no gromel for doubt oi hesitation as to the course which I have to nytiesue. 
By a perusal of the enclosed documents you will perceive, that after the detention of the Reindeer and Ruby by the master of the Dotterel, and while on their way to St. Andrews, "an attack was made on those vessels by two schooners and an open boat, under American colors. full of armed men, reith musliets and fized bayonets, amounting to about one hundred, headed by a Mr. Howard, of Eastport. who is said to be a Captain in the Urited States militia, in consequence of which the master thought it most prudent to surrender to such superion force."

This, sir, is an outrage of such a nature as to leave me no other alternative than to make a lormal demand from the American Government for the infliction of punislument on the offender's.

Whether the ressels were legally detained or not, such an act of violence will bear no justification. If individuals are permitted to expound the stipulations of treaties for themselves with arms in their hands, the preservation of harmony and good understanding between nations can no longer be hoped for.

I am disposed (uo person can be more so) to act fairly and openly by the citizens of this Republic, wherever they have just ground of complaint against Britisli authorities, and shall accordingly take every measure for ascertaining whether the detention of the vessels in question was legal or not.

If it was not legal, you have abundant proof, sin, in your own hanels, of the disposition of His Majesty's Grovernment to afford the most prompt and equitable redress to the parties aggriered. I a!lude to the case of the American schooner Charles, detained and cmployed as a tender last year by His Majesty's sloop Mrgus. 'Tliat act, you will recollect, was condemned as illegal by His Majesty's Ministers, and restitution ordered to be made to the parties who suffered through the exercise of it, although atherwise liable, by the illegality of their conduct, to the entire loss of their property.

But, in the meantime, sir, it becomes my duty to demand reparation, by the punishment of the transgressor's, for the act of violence perigetrated on persons bearing His IIajesty's commission, while en. gaged in the discharge of their public duties.

If fecl confident, sir, that you will view this outrage in the same light as mysell, and consider such conduct equally dangerous to the peace and well being of the two countries; and I have no doube that yon will see the expediency of causing immediate proceedings to be instituted against the principal acto:s in this disgraceful scene.

I beg, sir, that you will accept the renewed assurances of my distinguished consideration.

H. U. ADDINGTON. 
Kear Admiral Lake to Mr. Addington.

Hatifax, 9th September, 1824.

Sin: I have the honor io transmit to you a copy of a letter, dated 2Gth ultimo, from Captain Hoare, of His Majesty's sloop Botterel, with its enclosure fiom Mr. John Jones, Master of that sloop: also copies of two letters from Captain Hoare, chated the af instant; one of the'm containing a copy of the aflidarit therein mentioned.

By the lisest of these communications. you will perecere that two American vessels, called the Reindeer and Rulsy, were scized lyy the Master of the Botterel, in Two Island Harbor, Grand Menan, on the 2fith of July, for a breach of the treaty between Great Britain and the Cnited States; and that, on the evening of the same day, when ahreast of Harbor de Lutc. jurocceding to St. Andrews, an attack was made on the vessels in question, by two schooners and an open boat, under American color's, full of armed men with muskets and fixed hayonets, amounting to about one hundred, having the appearance of militia men, and headed by a Mr. Howard, of Eastport, who is said to be a Captain in the United States' militia; in conserquence of which, whe waster thought it most privident to surrender to such superior force.

Caplain Hoare's next letter mentions his having, on the 29th ult. on his masage to Iralifax. fallen in with the American schooner Madismon. (by her papers Ansel Coggins. Master.) which he was informed was cae of the ressels to which the men belonged wh: rescued the heforementioned ressels from his master: and that, finding on board this is cel a man. namel Danicl Rumney, whom one of the marines of 1h.e Dotterel identified as one of the persons concerned in the rescue, Captuin Hoare thought proper to detain the ressel, and take Rumney on board the Dotterel as a prisoner.

Caphan Henre's other letter refers to the Pilgrim, an American fishing ressel. seized by him at Grand Menas, in June last. for a breach of the treaty: which ressel was afferwards rescued by some of her crew, in conjustion with one of the men whom Captain Hoare hast put in charge of her; and the said ressel. having been fallen in with on the 29th ultimo. and a nan named Winslow, who, Captain Hoare was informed was one of those actively engaged in the forciWhe rescue of the said ressel, she was taken possession of, and the man ( $\mathrm{H}$ inslow.) put on board the Dotterel as a prisoner.

As in these Uransactions, His Majesty's oflicers have been assanlted in the execution of their cluty, by armed subjects of the United States, and the property of which they had, in Ilis Majesty's name, taken lav ful pensscssion. rescued from them in violation of the treaty subsisting brtwen Great Britain and the Lnited States, I consider it neeestary that the subject should be brought oflicially before the Amewean fovermment, in order that steps may be taken to prevent the 
continuance of such pracedings. and therefore recuest you will be pleased to adopt such measures on the occasion, as shall appear to you to be necessary.

Ihave the honor to be, \&c.

Rear Admiral and Commander in Chief,

\section{Captain Hoare to Reas Admiral Lake.}

H. M. Sloop Dotterei, 26th August, 1824.

SrR: I have the honor to enclose the copy of a letter firom the masaer of His Majesty's Sloop, under my command, detailing the circumstances of his haring been attacked of Campobello by two armed Schooners, under Ameriran colors, and that two Anerican fishing ressels, he had detained, were taken from him and carried into Eastport.

\section{Thave the honor. \&c.}

RICHARD HOARE, Commander.

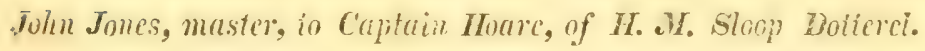

H. M. Shoop Doteterex's Boit,

$$
\text { St. Andrew's, N: B. 2"th July, } 1824 .
$$

SrR: I beg leave to represent, that, ou the 25 th inst. when cruizing in the Yawl, in pursuance of your order's, off the Grand Mena!n, ion the protection of our fisheries, I receired imformation of sereial American fishing vessels being at anchor at Two Island Farbor, and that two of them, name?y, Heindece and Ruby, of Lubec. were at White Island Harbor on tise 24 th, where they got their wood and water, and that, on their anchoring, they fired their muskets and told the inhabitants they were armel, and would not allow any man of war's boat to board them; and alter they had their supplies they shifted to Two Island Harbor, Grand Menan.

I made sail from Gullcove, and at day light, the 26th, observed four schooners at anchor at 'Two Island Harbor, which ressels got munder weigh on our appearing: when I got close to three of them, they lashed alongside each other, and all hands, about thirty in number, went on bard the middle one with their fire-arms and fish spears. I desired them to separate, which they refused to do until it threatened fo fire on them. On boarding, they proved to be the Reindecr, master"s name, Small, and Kuby, master"s name. Small, (brothers, of Tuber, two fishing ressele, and Friend's shallop, of the same place. 
It being the weather, and they not being in want of wood on' water, I detained the Reindece and Ruby, and put their crew, with lhe exception of their masters, on board the two American schooners, with provisions for a passage to Lubec, and made sail in the Reindeer and Ruby for St. Andrews throngh East Quoddy. About six, P. M. "I heu abreast of Ilarbor de Lute, I observed two schooners and an open boat, full of armel men, muskets and lixed bayonets, loisting American colors; one of them went along side. Mr. Townean in the Ruby, boarded and took the arms from him and his three men: the one abreast of me was kept off for about a quarter of an hour, when they commenced fring into us. Though with great reluctance I thought it most prudent to surrender to such superior force, having brt four men, one musket, and three cutlasses. On delivering them (1), I found there were in the two schooners about an hundred armed mine (including the crews of the schooners, about $30 \mathrm{in}$ number, ) the vest having the appearance of militia men, and headed by a Mr. IIowsird, of Eastport, said to be a Captain in the United States militia.

\section{I have the honor to be, \&c.}

JOHN JONES, master.

\section{Lapt. Hoare to Rear Admiral Lake.}

\section{H. M. Sloop Dotterie,}

Halifax Harbor, Sept. 2, 1824.

Sin: I have the honor to inform you, that, while running past the ontel bank of the Grand Menan. on the 29 th ult. on my passage to this place, I fell in with the Madison, American fishing schooner, (by her paper's, Ansel Coggins, master') and, as I was informed by Winslow, one of the crew of the Pilgrim, American fishing vessel, and who was then on board the Dotterel, that she was one of the schoners that attacked the Master off Harbor de Lute, on the 26th of July, and the Master having aflirmed that the name of the ressel that atlacked him was the Madison, though he cannot swear to the vessel, as all that description of ressels are so much alike, but he believes her to be the same; and, on the crew coming on board the Dotercl, one of them, Daniel Rumney, was immediately recognized hy Willian Vickery, one of the marines in the boat with the Master, as being one of those who were in, and took an artive part in, the vessel that attacked them, and, on boarding the said Madison, it was discorered the master had left her, and, as she had her boat out, I have no doubt lie hat gone on board one of the other fishing vessels to acrape detection, as lie would have been immediately recognized by the Master; and, as some dates on the back of the papers relative to

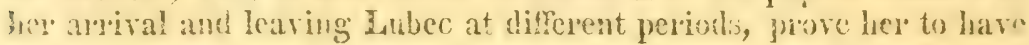


been at Lubec about the time of the Master's having bcen attacked; these circunstances, together, left no doubt in my mind of her being: the Madison, that, with another schooner, named the Diligence, attacked the Master of Harbor de Lute, on the 26th of July, and I therefore took possession of her, and ordered her to this port; as it appears to me, sir, that the circumstance of two armed schooner's attacking and taking from a British officer and boats' crew, two vessels he had legally detained, is an act of piracy, and all those concerned therein, ought to be punished.

I have, for the present, detained Daniel Rumney on board, and I have to request you will be pleased to solicit the advice of the Attorney Gencral on this important subject, that may be guided thereby in iny proceedings relative to the sairl Daniel Rumney.

I have the honor to be, \&c.

RICHARD HOARE,

Commander.

Captain Hoare to Admiral Lake.

His Majesty's sloop Dotteret,

Halifax, Septeнıber $2 d, 1824$.

Hru: I hare the honor to inform you, that, while running past the Outer Bank of the Grand Meran, on the 29th ult., on my way to this port, I fell in with the l'ilgrim, American fishing schoones, and. as this ressel had been taken by one of my boats on the 16 th of June at Grand Menan, for infringing the treaty, but was retaken by the crew, aided by James Martin, one of the two men put in charge of her, I have taken possession of, and ordered her to this port.

Enclosed, sir, is the copy of an aflidavit made by William Paine (marine) and the other man in charge of the l'ilgrim on their arrival at Lubce, by which afidavit you will see, sir, that a man by the name of Winslow, one of the crew of the Pilgrim, was the most active person in retaking her, and that he forced the cutlass from William Paine and obliged him to go below. Under these circumstances, I felt I should be justified in considering him a prisoner, and, as such, he now remains on board the Dotterel. That he ought to be punished in some way that may deter others of his mation from committing the sane offence under similar circumstances, I am sure, sir, you will think necessary.

I have, therefore, to request you will be pleased to solicit the aulvice of the Attorney General on this important point, that I may be governed thereby in my proceedings.

I have the honor to be, \&c. \&c.

RICHARD HOARE, Commandel:

Admiral LAKE. 


\section{Copy of the enclosure in the foregoing letter.}

Willam Panc, one of the matines belonging to His Britannic Ma. jesty's brig the Dotterel, maketh oath and saith: 'Ihat, on Wednesday last, the American fishing loat Pilgrim was scized for a violation of the taeaty between the United States and Great Britain, and the deponent, with James Martin, seaman, put on board to take charge of her: that, on the night of the 21 st instant, between the hours of 11 and 12 , it being Martin's watch. he, this deponent. was awoke from slepp by the roll of the vessel; that he attempted to go on deck, but fount fin companion doors shut: this deponent then broke open the

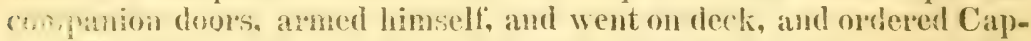
taisi Prodward, the master of the boat, then at the helm, to put the bout abont: he rofused; Martin was rowing; this deponent went forward and ofdered him to drop the oar: but he would not till this depoment thratenci to cut his lead wit il he did not: whe this deponent Was thus cuterarong to get the ressel albut. Winslow and Martin suredinly sping "pon him, and obliged him to go below. This deponest ":as then brotight to this place in the said boat l'ilgrim against his will, and aganst all the exertions in his mower to make.

$$
\begin{aligned}
& \text { WILLIAM PAINE. } \\
& \text { mark. }
\end{aligned}
$$

Benjamin Scoti, one of the hands on board the Pilgrim, on oath, sath that the foregoing statement of $\mathbf{M r}$. Willian Paine is, according to his best knowledge and beliel. substantially teic; that le was below wlen Mr. Paine armed himself and went on deck, and soon after he returied and sath he had been orepowered and his arms taken from lim; that the P'ilgrim was taken by Woodward and Winslow, arded by Martin, to Lubec. This feponent further saith that Woodward aud Winslow both acknowledge that Mr. Paine discharged his duty in the numest of his power: that superior force alone caused him to surrender his arms.

BENJAMIN SCOTT.

\section{$\left.\begin{array}{c}\text { State of Muine, } \\ \text { Washington, }\end{array}\right\}$ ss.}

T'in all to whom these prescuts may come, Kuow ye, that, on this twenty-secomil day of Junc, anno Domini is 21 , before me, Solomon Yuarn, Notaly Public, by legal athority duly commissioned and sw: ofis, atud residitig at Lubec, personally appeared the afore-named Wilian l'able and Benjanin Scott, and male solemn oath that the dectations by then persmally made and signed were just and true. 
$\left.\begin{array}{l}\text { Vew Brunswick, } \\ \text { Charlotte County, }\end{array}\right\}$ ss.

Halifax, September 2d, 1824.

I, the undersigned, one of His Majesty's Justices of the Peace, in and for the said county, residing in Canpo Bello, do hereby ce:tit?. that, on this twenty-third day of June, 1824, William Paine, tle person in the annexed instrument mentioned, appeared before me, and declared tive facts therein contained, which appear to me to be correct. That Solomon Thayer is a Notary Public for the County of Wash. ington, in the Province of Maine, United States, duly appointed, and that full faith and credit may be given to his attestation.

Richard Hoare.

D. OWEN, . . P.

Commander of IIs Majesty's sloop Dotterel.

Mr. Shepley to Mr. Adams.

Sico, November 16, 1824.

Sir: Having been requested, by letter from Mr. Brent, under date of the seventh of October last, to institute an inquiry into the circumstances particularly complained of by the British Charge d'Affaires, and to communicate the result to the Department; I have now the honor to inform you. that I repaired to, and near to the places of residence of the parties to those transactions, called upon them, and took their statements under oath, which are herewith enclosed, and by which you wil be enabied to understand fully and correctly, the whole history, not only of the circumstances complained of, but of all the proceediugs of the Captain of the British armed brig Dotterel, in relation to our fishermen; and their proceedings to protect themselves, as they supposed, from the losses occasioned by the conduct of the Captain of the Dotterel.

It may, I think, sir, with safety, be aflirmed, that the enclosed documents (being the affidavits of twenty-geven individuals, and relating to thirteen schooners and boats, and one small boat,) present a fair and faithful history of ali the proceedings this season, between our fishermen and the officers of that vessel.

I have been particularly cautious, in taking the testimony, to give it without coloring it by the feelings of excitement manifested by ous' citizens.

Enclosed, also, is a bill of services and expenses for attending to the business.

With the highest respect, I am,

Sir, your most obedient servant,

ETHER SHEPLEY,

Histrict Altorney. 
I, Rubert Small, master of the schooner Reindecr, of Lubec, w: oath, testify and say, that it is my practice, in fitting out fur the fisheries, to fill the barrels, which 1 use for oil barrels, with water. and, as I use the water and empty the barrels, to fill them with oil. I purcluased the barrels while fitring out this cruize, and did not ser lhem till after filled: there were eight filled with water. We left the harbor the twenty-sixth day of $\mathbf{J u l y}$, and procected on the fishing ground near Grand Menan lsank; continued to fish two or three days, and then discovered that the water in six of my bancls was salt, so that I could not use it; the barrels having becn used for salting beef and pork. Fnding my water all bad and expenced, ran in to 'I'wo Island Harbor' for' water, and went on shore and obtained my water; laid there till the next moining; becalmed; then made sail for the banks; got out about a mile and a half, or two miles, and the wind died away, and left me becalmed again; soon discovered the barge of the British armed brig Dotterel; the Ruby, the Friend and boat Diligence, Jying in the same harbor, and near me; the barge came up and fircd: ordered the anchor to be dropped, which was done: the master of the barge then ordered us to part, Ule Ruby and Reindee! being connected by a small line, which was obeyed: the ressels parted: he then ordered the Ruby to drop her anchor, which was done; he then came on board our ressel, the Reindeer, in a great rage; he demanded" the "Wapers, which were given him; they then threatened to carve uss up like a lurkey, or a piece of beef, brandishing their cutlasses about our heads; took the crew all out, and put them on board the schooner Friend; then took ont the crew of the Ruby, and put them on boasd of the schooner Diligence, and ordered the Friend and Diligence off; told them to go off and about their business; then got the Reindeer under way," bound for St. Andrews, and ordered the Ruby to follow; passing up a little past Harbor do Lute, two other vessels hore down upon us; one, the schooner Madison, came down upon the Reindeer, there being about twenty men on her deck, with muskets, but no bayonets upon them; Jones, the master of the barge, being on board of the Reindeer, cridered all hands, and directed tirem to fire into the Madison: I then said to him, if you fire into that vessel, every man of you will be shot: he said, I believe it; he then said," what do they want, and who aro they? I said to him, they are my neighbors: they want this vessel, and they will have her: be then laid down his sword and said, I surender; unlocked his trunk, took out the papers of my ressel and the Ruby, and gave them to mo. Skipper: Coggins then invited him on board the Madison; and upon my assuring him that lie might go with perfect safety, he went on board, drank with us, shook hands, and parted with us; went on board his barge. and went off; the Reindeer and Ruby then went home; the vessel has been laid up since, as I did not dare to let her go out; and the crew has been upon charges also: the injury to the owner and crew has been fifteen liundred dollars: I was in no other British harbor, except at Buck's Rock, in Grand Henan, where I went in the night in a heavy blow, and went 
aut again before morning. I saw no person; was not on shore; ncver fired any musket on the island, nor did $I$ ever state that 1 was armed, or intended to resist; had only one old musket on board; fishermen always carry one or two: the crews of the vessels Reindeer, Ruby and Diligence, were not on board the middle one, or any one of the veysels; nor was there any shew of fire arms, or fishspear's, on board of either of the ressels; they were not lashed to. gether for resistance. This is not only a common practice, but is necessary in this Bay. where the tide is very strong, and runs in different directions. 'There was not a gun fired into the Reindecr, or' at her. while in Jones' possession, nor was there a gun fired at all, till after Mr. Jones had gone on board the Marlison, and then only as an expression of joy; nol was there any gun fired at the Ruby, nor did the Diligence, nor any person on board of her, demand or take, any arms from those on board the Ruby, when she was retaken: they did ask for one of their own muskets, which the barge had taken from them. and it was brought to them: this was after the Ruby had been surrendered. I have not fished any, within five to six miles of the land this year. 'There is no fishing ground nearer the shore, nor any gbject in going near shore, except for wood and water.

ROBERT SMALL,

Sworn to bofore,

Nevember, $5,1824$.

\title{
E'THER SIIEPLEY.
}

\begin{abstract}
(19)
\end{abstract}
Paul Jolinson, Jumr. master of the Schooner Sally, of Eastport, on vath declares, that he sailed; the thirteenth day of May last, fitted out for the fishery on the Labrador Coast, and procecded on the voyage; on the 4th of June, the wind being east, and weather coming on thick, thought it prudent to make a harbor and ran into Shelburne, on the south side of Nova Scotia, and anchored, and was boarded by a boat from the British armed Brig Dotterel; was asked what business I had there? I told him was bound to Labrador and thought I had a right to make a harbor. Tho Sally was then ordered under way, and carried alongside the brig, and an officer came on board and searched us, was told I had broken the treaty; and should be detained. The next morning my whole crew were taken out and put on board the Dotter$\mathrm{el}$, and my vessel was manned from the Dotterel and sent on a cruise to Cape Negro Harbor, about nine miles, there several small vessels were boarded from us, continued there two days, then got under weigh and proceeded back to Shelburne and anchored along side the Dotterel. The captain then sent for me to come on board the Brig: went on board, was asked if I was master of the Sally-answered that I was. He said he did not know but my vessel would be condemned if he carried her in, but he should let me go, was told I must pay for my men's rations while they were on board the Dotterel, and I sent 
on board the Dotierel fifteen pounds of pork and eighteen pounds of hread, and then took my men on board asain and proceeded on my voyage.

PAUL JOHNSON, Jun.

November 5th, 1324.

Sworn to befure

ETHER SHEPLEY.

1, Mebbert IIunt, skipper of the schooner Galleon, ofLubec, and Banicl Joy, Jr. Nehemiah Small, John Hunt, hands on board, on oath, testify and say, that we sailed, in said schooner, from Lubec, the first day of July last, fitted out for the fisheries, and proceeded fol the fishing ground ncar Grand Menan Bank, being on the passage, and six miles distant from tire southwest head of the Island of Great Menan, the Provincial Revenue Cutter, Mr. McMasters master, came down upon us and fired upon us: ordered us under his lea. We hove too under his lea; he sent his boat aboard; demanded the papers, which were delivered; searched the ressel, and then dismissed us, saying we might proceed on to the banks. We then proceeded to the bank, and continued to fish fifteen days on and near the bank from fifteen to eighteen miles distant from the laml: then, being in want of water, having lost part of our water by injury accidentally happening to one of the casks, and being also in want of wood, found it necessary to make a port to obtain wool and water; ran for the Island of Grand Menan, and made it a little to the north of Woodward's Cove; obtained our water, and then proceeded to the mouth of Beale's rassage to obtain wood, being unable to obtain it where we did our water, and there obtained a boat load of drift wood; towards night, being below eating our only meal for the day, having neither wood or water to couk before, were boarded from the bargo of the British armed brig Dotterel; was asked where the vessel belonged; our pafers were demanded and delivered, and the vessel was immediately ordered under' way. 'The skipper' stated to the master of the barge that he came only for wood and water; that he had not fished any near the land, and thought he had done nothing which he was not authorized to do by the treaty. 'The master' of the barge said, what is the use of talking about the treaty-damn the treaty-I did not come here to learu my lesson-I learnt it before I came. One of the hands, named Joy, was threatened to have his mouth gagged with the pump bolt for conversing with some of the crew of the barge, and was sent on shore on White Head Island; the vessel and remainder of the crew were carried to St. Andrews; the vessel was afterwards sold at St. Andrews; the crew were turned out of the vessel, and every thing detained but our wearing apparel. The loss to the owners and crew has been as much as one thousand dollars. We have been on board of the schomer during all the tinte she was enployed this scason, until taken, and do positively aver that we have not fished, at any time, within more than six miles of the land, aud have not, at any other time, been within any British harbor. 
We also tostify that, about the middle of June last, being on the gravelly ground about nine miles southeast of the island of Grand Menan, Jacob Winslow came on board of us from the schooner Pilgrim, to borrow an anchor, stating that they had lost their anchor; having broken one anchor, could not lend him one. The next day, the Pilgrim being at anchor about half a mile outside of us, and more than nine miles from the land, soon got under way to go home and obtain an anchor; and, having passed us nearly a mile toward the land, a tender to the Dotterel came down upon her, and fired upon her, and took possession of her, she then being eight miles to the southeast of Grand Menan. 'The same day, about an hour after, the tender. took possession of the schooner Hero. of Dennisville, Clark master, she being, at the time, about a mile outside of us, and ten miles south east of the Island of Grand Menan.

Sworn to before

HEBBERD HUNT. NEHEMIAH SMALL. DANIEL JOY, Jr. JOHN HUNT.

\section{ETHER SHEPLEY.}

November 5th, 1824.

John G. Faxon, of Lubee, on oath declares, that he was the ownet of the Galleon, when she was captured by a barge of the brig Dotterel. On or about the seventernth day of July last, the Galleon having been captured, and lying in Snug Cove in Campo Bello I went on hoard of her, to learn the reasons of her capture. The Master, Jones. informed me, that he had no other reason for the capture, than finding her in a British Harbor in Grand Menan. I then asked him, it he was not aware that we had a right to go in for wood and water? he said he knew we had that right, but his orders were such, that he was obliged to take all, whether in for that purpose or not. I asked if he had known, or suspected my vessel had fished near the land. He said, he never had. I then aslied him, if he had not reason to believe they were in want of wood and water, when they went in. He said he had, for the wooi and water was on deck, not stowed away, when he trok them. I then asked him, how long hesupposed they hat been lying at anchor. IIe said the men told him, thee quarters of an hour, and he liad no reason to believe otherwise. I then said, bx your ov $n$ statement you ought not to have taken her. He said. he should not have taken the fralleon, if he had not before taken the Willian. and should have let her go, if he could have done it, without ex. cusing the lillian. He then wath, as I have then thes far, I mast carry then to st. Ambews; hat $\mathbb{I}$ give you my word, you ves sel wil! not be detained tuo home. I then rebleased that part of the treaty to him, anthoriang onr vescels to go is for wood and water. Ilesaid the were authorized to tale all vessels within three miles of the 
land. I afterward heard the orters giren by the Captatia io Jones, I'cal: they directed him very nearly, and I believe, exactly as follows:

"You will consider your cruising ground to be tho Menan Islands. Campo Bells, and the Island of Lubec. You will take ald American fishermen found within three miles of the land except in extreme cases of distress, and carry them to St. Andrews, there take an inventory of the articles on board, and deliver the sane to the Custom House."

\section{November 6th 1824.}

Sworn to, before

JOHN G. FAXON, ETHER SHELPEY.

I further stite that I sent an attorney to St. Andiews, to ascertain the expesiency of defending the vessel; that I learnt through him, that I must first give a bond nf seventy pounds in pay costs. That the costs must be paid by me whether the defence was successful or not, and that there was little prospect of obtaining a decree of restoratinn without having an appeal entered; and that the expense attending the trial would probably exceed the value of the property; and therefore declined inaking any defence.

\section{JOHN G. FAXON.}

November 6lh, 1824

\section{Sirnern to, before me,}

\section{ETHER SHEPLEY.}

1. Dones Wass, of Adlison, in the state of Maine, testify, and say. that i was master of the schooner lecbecen, of Addisom, of the burthes of about twenty-seven tons: that I sailed from Aildison on the first diay of JuY, 1824, ii the said schoon'r, fitted out for the fisheries; that 1 procecled in said schooner, and made the "Mlur. Ground," about fifteen niles; south east of the Island of Grind Menan, the same day, and anchored the next morning; caught a few cuintals of fish: it came on to blow freshe, and 1 went in and anchored atout half-at-mile from lamkl. under the Island of Grand Menan: went on shore in a boat, with a barrel, and obtained a barrel of water, for whin 1 went to tio Island; aml having put the water on boad. get under way, and standing off to tige fishing fround, perecined the barge of the British gon brig Iotterel giving chase, and continned to procent wat the same conise, the barge still pursuing till ewoning it being abont 3 oolock,

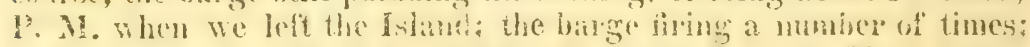
at dark we lost sight of the basege, being then anenp the Noba Scotia shore: then reformed partly back to the fishing gremat, and hove to under the forewail. and the uext monning cane in and anchored at Gullere in the Isla a of Grand Menan, where vere six other American vessels; got unicr way again an hour allere sum-rise, and stood out to sea: the wind blew se tresh that we could not anchos on the

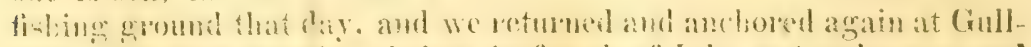

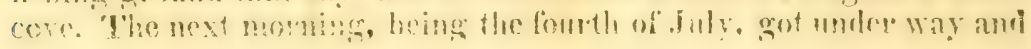


procecled to the lishing-ground first mentioned, and on Ionday, the fifth, continued on the Mur Ground, fishing: oin 'Tuestay, the sixth of July, in the morning, the wind blowing fresh, we hove up and laid to under her foresail, and about $8 v^{\prime}$ clock. A. M. weather being thici, and nearly out of wood, went into or near' ('ull-crive. About 10 o'dock, the barge came alongside, all hands being employed in dressing fish, and ordered us under way, and said he wats ging to carry us into St. John's: demanded my papers, which were given up. I declined ilarigating my ressel by order from the barge, and the master of the barge directed his uwn crew to get her under way, which was done. Wie were carrierl to St. John's in the Rebecca, and put us ashore, ant we mate the best of our way home, leaving the vessel. She now lies at the wharf in St. Joln's. No libel or proceedings have ever been instituted against the Rebeca, that I can learn; and have learnt from the collector of the port of St. Andrews, that, a few dass since, she liad unt icen Jibelled. 'The Rebecca was owned wholly in Addisim?, by W:imot Wass, Lemuel Wass, and myself. 'The place in Grand Menan, called Gull-cove, had been formerly pointed out by the British author. ities on the Iyland, as well as on the water, as the place where we should be permitted to anchor and throw the "gursy" oresboard. The loss to the owner's must be at least seven hundred dollurs.

JONES WASS.

.Vovember 1, 1824.

Sworn to before me, ETHer Sheptex.

I, John Wright, on oath, declare, that I was mate on board of the Robecca. and that all the facts, above stated, in the affidarit of Jones Wass, which have been read to me, are true.

November 1, 1824.

JOHN WRIGHT.

Sworn to before me,

Ether Shepley.

I, Charles Tabbut, on oath declare, that I was master of the schooner William, of Addison; that I sailed on or about the 27 th day of June, 1824, fitted out for the fisheries, and proceeded to the fishing ground on and near Grand Menan bank, and continued to fish frorn fifteen to eighteen miles distant from Grand Menan, until the thirteenth day of July; and, on the fourteenth, having lost some of our water, found ourselves in want of water, having only half a barrel on board, and that too bad for use; then ran into Grand Menan for water, that being the only place, as the weather then was, where we 
could obtain it; and on the fifteenth anchored at Gull Cove in Grand Menan; had been at anchor about ten minutes, when we were boarded from the barge of the British armed brig Dotterel, the papers were demanded, and delivered, and the men from the barge were ordered below to search for arms-found two muskets-took the arms, and knives. I asked the master of the barge what he was going to do with us? Hr answered that we had been damned saucy to the inhabitants. 'T'o which I replied, that I had never been ill used by the in. habitants, nor ill used them; I had never before been into the land, and could not have used them ill. The master of the barge then threatencd to (ut me into ounce pieces, to lash me to the deck, and to gag me with the pump bolt, or pump brake; the vessel was then got under weigh, carried near shore, and moored, and stripped, the boat taken away, and we were left on board the vessel, thus stripped, and deprived of the boat, and without water, and lying in a dangerous place. T'lie master of the barge said if we called a boat. or landed, or made any noise, he would shoot us. He passed us several times, and I called to him and asked for water; he answered that he would come to our assistance, but did not. Despairing of obtaining any from the barge, I called to the master of an English vessel, who aid. ed me with a boat to go on shore and obtain a little water; I went, and obtained a few gallons. The next morning, the master of the barge came on board again, and carried the ressel to St. Andrews, and reported to the collector there, that we were found in Grand Menan, in want of neither wood or water. After endeavoring to obtain a release of the ressel, without success, was ordered to leave the vessel, and did leave her. I asked the master of the barge how he could detain my ressel contrary to the treaty? He damned the treaty, and them that made it. The vessel was owned by William Wass, and William Nash; she was libelled, deemed forfeit. and sold, no person appearing to claim her; and the reason that no person claimed her was, that the costs and expenses, attending it, would be as much as the vessel was worth; the loss to the owners and crew, must be near two thousand dollars.

November $2,1824$.

\section{CHARLES TABBUT.}

\section{Sworn to, before}

ETHER SHEPLEY.

I, Josiah W. Perry, on oati deelare, that I was a hand on board the schooner William, that the facts, as stated by Charles Tabbut, are wholly true, the same having been read to me.

JOSIAH W. PERRY.

Norember 2, 1824. 
I. Christopher Wass, on oath declare, that I was managing master of the schooner Sea Flower, of Addison, my son being mastej, and sick on shore, and the ressel having, during the previous part of the season, been employed in the fisheries, and sailed on the twentieth of September, on the Grand Menan Bank, and continued there fishing: on Tuesday and Wednesday; and about eight o'clock, P. M. Wednesday, blowing fresh from the west, hove up the anchor and laid to under the foresail. 'The wind, luring the night, dhew into the northo west and blew very heary, and split her loresail; reeferl the sail above the rent and set it again, and loid till day-light: then stood to the northward and eastward, and made the southwest head of Grand Menan, bearing north by east; made the Mur Rocks, and obliged to go between them, and fetched in to Kent's Island near Gi'and Menan, being Thursday morning. Friday anci Saturday blowing lresh and storming, could not mend our sail. Sunday contimuing toblow fiesh, laid still. Monday went out on to the outer part of the rips, five or six miles from the land; canght a few fish, and contimuing to blow so that we could not anchor, came in and anchored again at Kent's Island. Tuestay went out to the rips again, still blowing fresh and raining, and heavy sea from the eastward, could not anchor, canght only a few fish, and in rumning in carricd away our fore-shrouds; hauled down the foresail and ran in to the same habbor again. Wednesday morning was boarded from a tender to the British armed brig Dotterel; paper's were demanded and delivered; asked what business we had there; and was answered that we were riding ont the galle with both anchors ahead. 'The master of the tender, after much entreaty, consented to give up to us most of the fish and salt, and next morning set all hands on shore at Kent's Island, and carried the vessel to St. Andrew's where she now lies. No proceedings have been instituted against her that I can learn. She was owned wholly by me; and my loss will be as much as seven hundred dollar's. I have never heard of any complaints against the vessel, other than that she was found in the harbor, and was accused of going in too frequently during the last few days.

November 1 st, 1824.

CHRIST'OPHER WASS.

Sworn to before

Ether Sheplex.

I, Jones Wass, was mate of the Sea Flower at the time abovementioned, and have heard the aflidavit, signed by Christopher Wass, read; and, on oath, declare the facts therein stated are wholly true.

JONES WASS.

November 1 st, 1824.

Sworn to beforeEtuer Sueptex, 
I, Joel MI Kinsey, on oath, declare that I was a hand on board the boat Pover, of Addison, fitted oit for the fisheries; that we sailed the first part of the montlı October, 1824, and proceeded as far as Little River, where we lay about nine daye wind bond, and canght some herring: went ont on Friday moremg for the Seal Islands, but finding the wind unfavorable, concluded to proceed to the southwest head of Grand Menan. and laid to six or seven miles from the Island to the westward, fishing; while lying in this situation, a tender to the British armed brig Dotterel passed hetween us and Grand Menan castward, and wont round the point of the island out of sight; we continued fishing, and drifted nearer to the island, and tho tender, about the middle of the day, returned and fired a gun toward as, we being then to the westward of the island, and distant from it four or five miles; the tender came up and spoke to the skipper of the boat, and asked him what business he had there; he answered, that he had a right to fish there, for he was in our own waters; our papers were taken, and we were ordered to follow the tender. and followed her into Seal Cove, in the western end of Grand Menan; where we were sent on shore. and the boat started for' St. Andrews. 'T'he boat was owned by Wil. Jian Nash. 'The loss to the owner will be about two hundred and fifty dollars.

Norember $3 d, 1824$.

\section{JOEL MCKINSEY.}

\section{Sworn to before}

ETHER SHEPLEY.

1, Otis Bryant, of Jonesborongh, on oath. declare, that I was skipyer of the boat "scape, of Jonesbonough, belonging to Jeremiah Smith, and sailed the forepart of October, fitted for the fisheries; procecied to Little River. and wind being aheal and blowing heavy, could not proces on to the fishing gromals, and remained in Little River eight days, and then proceeded toward the island of Grand Menan being from three to fum miles distant from the sonth rest point of the island, the tender of the British amed brig Dottepel came down upon us, and fired at us, and put a man on board, and directed us to follow; took the papers and carried us into Seal Cove, in Grand Menan. 'The next morning we were directed to leave the boat and go ashore, and did so; the boat started for St. Andrews. 'Ihe loss to the owner and crew must be two hundred and filty dollars.

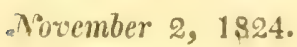

OTIS BRYANT. 
Moses Smith, on oath, fleclares, that he lias attemded to and henrel pead the statement signed by $O$ tis Bryant, and being a han! on boare? the boat, knows the facts therein stated are true.

Sworn to before

MOSES SMITH.

ETHER SHEPLEY.

November 3, 1824.

I, Jacob Winslow, of Dennysrille, being a hand on board of the schooner Pilgrim, of Dennysville, James Woodward master, sailed from Lubec about the 11 th day of June last, and proceeded on to the outer grounds of the Island of Grand Menan, and besan to fish the 14 th, being then from 10 to 12 miles distant from the Island-wind blowing fresh, and tide strong, bioke an anchor, and struck adriftgot under way, and dressed one fish. The next day went on board of the Galleon, fiunt, to bortow an anchor, and could not obtain one; next morning anchored on the ground called the gravelly bottom, near the schooner's Galleon aud Hero, and distant from 8 to 10 miles from the island, caught from 10 to 12 quintals of hish, and then struck adrift-then, finding ourselves unable to work to advantage with one anchor, and that a iight one. concladed to go home to get one; about half an hour after, a ressel from the southeast came down upon us, and fired several times. came on board, and jroved to be a tonder to the British armed brig Dotterel, demanded, and took our paper's, and took out two of the hauds. myself and Benjamin scott, and put us on board the tender; asked us what we were doing there, and answered had been fishiug; master of the teuler said we had no business to fish there in British waters, and would nake us simart for it this year; he asked me what land it was in sight; said he had never seen it before; was told it was the Island of Grand Menan; asked if there was any harbor inco which I could pilot him, and being informed there was, asked me to pilot him in, which I dis; before was carried in, master of the tender asked what vessel was alicad of us, told him did not know; he said lse would know, and bore down upon her, directing the P'ilgrim to follow; he ordered a marine to fire upon the vessel, and he fired several times; soon came up with her, and she proved to be the schooner Hero, and boarded her' inquired why they did not heave too at the fir'st fire; master of the lifero answered him, that no colors were shewu, and he did not know that any thing was wanted of him; the paper's of the Here were then demanded, and delivered, and two men taken from her and put on board the tender, and two of the tender"s men put on board the schooner; the tender was then piloted into a harbor by me, taking "itli ine the Pigrom and Hero; master of the tender inquired if there was any curtom-house oflicer of

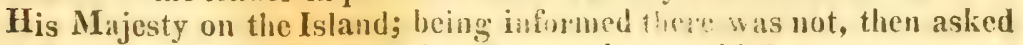
if there was any other King's oflicer, and wis told there was not, except a pilot; then went ashore, and examined till about 110 'clock at 
night, when, with dificulty, he came aboard again, and was very violent; laid there three days. then got umder way, and went up to the Woives Islands; and went ashore; tarried there a short time, then asked me to pilot him into Beaver harbor; there ordered all siils of his own and the two other ressels unbent. and carried on shore; then asked him to permit me to go home, as I had done before, but he refused; told him, would give him a bill of sale of the boat if he would let me go, she being minc, but he declined; l complained of hard treatment, and he threatened to shont me, and to tie me; next morning directed sails brought on board cond ient; sot under way, and beat out of the harbor. brund, as lie said. to St. John's; saw a ressel, and inquired if had seen an armed brig, being answerod that had scen her at St. John's, we returned to Beaver harbor, and tarried that night, then started again fot St. Johns; beat up about haif way to St. John's, and anchored in a ploce called Mason's Bay in the evening; about 10 o'clock the cockswain came on board the Pilgrim, I having been previ. ously sent on beard of her so sleep, and brought a pint of rum, and ordercol men to kecp a hirict waich, and left us: as soon as the lights were out on board the tenter, one of tie men on board of us from the tender being below astect, the ofles nne jroposed noing away with the l'ilgrim to the Unied statrs. We soon got the l'ilgrim under way, and started for Luber. 'The man who was bebw asleep then came on deck, and askcl where we wive gning. I toll him to Lubec. He told me as there was but little wind, he theaght we should be caught; and had better go back. I said we wnall keep out of their ieach. IIe said, if taken, they whlld shoot hian: and then went below, and soon came up with two cutlasses, and said be would split any man's brains out in the King"s wame, that ollered to resist lim. 'Ihis it was advised that he shonld do, to clear him from Larm, in case we should be taken; he laving agred, beinevestarted, to the adventure; and he ordered the man to desist who wa: yowing, then knocked off Captain Woodward's hat. I then went and teok one of the sword's from him, and the

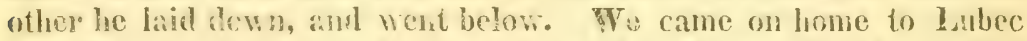
with the vesset, ohaincd an anchor, and in fon or five days after sailed again on to the bank of Crmat Mevan, fiftecn miles or more distant from the Island, and conthued there fishing four or five days; one of the suen who cane irom the Doterel still continung with is, by his own desire. Was incormed that the schooner Hero, an American vessel, which had been cantured, was fitting out and armed by the British to take me: saw the llego, soon after, boarding several vessels, and got muler way and went uy to Mourt Desert, and fished there four or fire wecks, and then returned to Dennysville, and washed out our fish. and eight days after sailed again, and went on to Marblehcad l3anl, so called, and began to fish: the island of Grand Menan bearing north uortheast, eighteen leagues distant, and continued to fish there six or eight days; then stood in to Grand Menan bank, being five or six leagues distant from the island, and anchored, and laid to, being Sunday, and all turned in. Soon the brig Dotterel came upon us, and sent a boat with five men on board, with cutlasses 
drawn-inquired for Martin, the man who had come away with us, and continued to fish with us. I told hin I din mot know-believed he had gone to Boston; asked me if I wats shipper of the vessel, and answered f was in place of one; acker tor the papers, and I declined delivering ihem; told him they had one set of her papers; "as toli to get into the boat and go on board the brig, and did so. T'iney then got the P'igrim maler way; the captain of the botterel asked my nane: was told it; said he had got a prety good history of my cliaracter: told him ithat not robbed any botiy, on killed any one, or stole any thing; he asked for hantin; was bold I did not know: believed he had gone to Boston; then said to him if you are going to keep the resset, if you will put me on bourd one of these fishernen, that I may gohome, shall be much obliged to you liome! said he; yes; if you want to go home, I will carry you houne to Halifax, where I will have gou tried and hung. I asket him to let me on on board the P'ilgrim and get ny chotles. lie said no, damu you, you shan't have any clothers: asked again for my chothes, ant was permitted to go and get them: asherl him if lie was to give me any theng

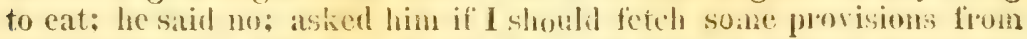
my own vessel, and how math: he satd ietch a lecte's provision; went aboard the Pilgrim, and was putting up sone prosision, when Jones, who was on board, and had command of the l'ilgrim, callcri ne up; told him the Captain told bor to get some provision, but he would not permit we to get more than twelve or

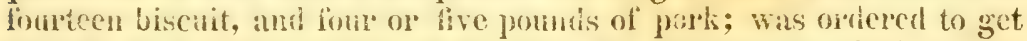
into the boat and go on boand the brig. By this time they had scarched in the hole of the vessel, and found liartin hid there, and put him in the boat. When we went on board the brigg, found five or six malines, with muskets and fixes bayonets. 'They took Martin and carried him below. I was seat aft, and liept there, gitarded by marines, till eight or' nine o'clock in the evening. Soon alter, was sent down the efter hatchway, and shackiess put tipen my ancles, and a large ba: of iron put through them and lastenes to the dech, and an old siail, with the 1'opes in it, given rue to he on; and then I was kent four days, then took out and carried ne under guand ripon the yiarter deck, where I found the oflices's paraded. Captatin charged me with threatening their men's lives, and threatening to throw them wrerboard; I told him I hat done no such thing: he said Patine (who was the man on board the Pilgrim that came wip with the swortis) laie told lim so, and that I would have done so unless 1 had been prevented by Scott, one of my own men. I told him I could not have used a brother better than I did Paine. Captain then said if I would tell him where the Ruby and Reindeer were, would let me go with iny vessel. Told him did not know, and if I did would not tell him.- ite had now arrived at Halifax-asked the Captain what he should do with ue-le said I should be carried to St. John's and hanged. Asked him for something to eat, telling him iny own provisions were all gone-he said I ought not to have any thing to eat. The next day I asked him again for something to eat, having had nothing- said he had not yet 
secn the Armiral, and I conld have nothing till he had seen him. I then told him I hat robber no one, was no pirate, but thought he was; for if I was to he pat to death he should do it like a man, and not starve me to deati-loish him $f$ wished to go ashore and be put in jorison. On the fourth day after I mate application for food, and had none for all this time, was taken on deck, fold I was to go to Sto John's to be humg. and two-thirds of a sailor"s allowance given me, and continued this way sixteen days, and then cane out and caneon to the banks of Cromd Nenum; and the next morning made a harbor in New Brunswick: then went to St. John's, and Captain went on shore, and came back. and sent the Pilot dowa to ine, who told me to go to the Captan and tell him that you will give him a bond for sixty dollars to bring the vesse! to St. John's, and he will give you an orilen for her, and you talie gool care not, to letch her here. I went up, and Captain said, I suppose yon want to go home, don"t you? I answered yes. I suppose if yon went home you wonld give me a pretty nane, would you? 'Told him If would give him no worse name than he deserved. Then asked if evei I was in jail there. 'Told him no. He said I slionld be before night. Tohl hin I shonid prefer that to being on boarl. Ho then tolt me if I hat any friend; in St. John's that would give hilit a bond for forty dollars, I might go to bulitus and get my vesect, and bring her to St. John's. I went ashore in his boat, procures a bond, and brought it to him; then tohd me I must not give him a bad name, but be thankfil that he had let me go and given me ny ressel; tonk the bond for forty dollar's to deliver the vessel there in thirty days, and gave ne an order for ny vessel-said, you will take care, I suppose, not to come with her. 'Told lim thought I shoult. I thon quit his vessel, and came directly home. The vessel is still at Ifalifax, I suppese, I have not been after her.-Che above is a true history of the whole proceedings of the Pilgrim this scason. I have been in lien all tibe time. She has never been in any British hatbor except where mentioned, nor fisher in any other place than is above stated. - The loss of property is one thousand dollars.

November 5, 1824.--Sworn to before

\section{JACOB WINSLOW.}

Etruer Sireptey.

William IIoward, aged fourteen, on oath declares, that he, with iwo other boys, aged seventeen, and thirteen, last August took a small boat belonging to Mr. Thomas Brown, the boat having about fifteen feet keel, and went down the bay a fishing, and passed by the little island called the Thumb-Cap, about half a mile, and fished there about an hour and an half; then went towards Casco Bay Island, and fished perhaps three quarters of an hour-then started to come home; got up to Friar's Bay, in Campo Bello, and the Dutterel hailed us; we went up, and on board the Dotterel, and they took our boat and moored hor alongside, kept us until next morning, and then set us on 
shore on Campo Bello; they have detained the boat and usedher, and still do, as a boat for the Dotterel. Have often seen the boat passing in the waters with the Dotterel's men. We went out for pleasure fishing, and to get a fresh fish for our own use. William Howard is an apprentice to a blacksmith.

Norember 6, 1824 .

\section{WILLIAM HOWARD.}

\section{Swol'u to, before}

\section{E'THER SHEPLEY.}

Benjamin Newman on oath declares, that he has heard the statement signed by William Howard read to lim, and that the facts therein stated, except so far as they selate to the use of the boat by the Dotterel, are wholly true.

November $6,1824$.

BENJAMIN NEWMAN.

Swom to, before

E'THER SHEPLEY.

Thomas Brown on oath declares, that he was the owner of a small boat which William Howard, and two other boys, took sud went out to fish in; they came back without the boat, and said she was taken from them by the Dotterel. I went to St. Andrews to find her, and asked one of the officers of the Dotterel to let me have the boat, but was told I could not have her. I then applied to Mr. Dumn, the Comprtroller of the Customs at St. Andrews, to get him to intercede with the Captan of the Dotterel for the boat; he answered me that he could not, that no report of such a seizure liad been made to him; that the Captain was a bad fellow, and had the day before insulted the custom-house. I returned without the boat-have since observed her to be used by the Dotterel's men, and believe she is still in use as a boat to the Detterel. She cost me about twenty-two or three dollars, with the apparatus.

THOMAS BROWN.

November 6, 1824.

Sworn to, before

E'THER SHEPLEY.

I, Elisha Small, master of the schooner Ruby, of Lubec, on oath testify and declare, that I sailed the eighth day of July, fitted out for the fisheries, and went on, and neat to, the Grand Menan Bank, and continued there to fish sixteen or seventeen days; then ascertained that our wood and water were expended; the wind blew heavy from the north, and alter attempting, without success, to gatin the American shore, put in to Grand Menan, in Two Esland harbol, to procure wond and water; this was tho twenty-fifth of July, in the alternoon, 
and laid thore till the next morning, having obtained my wood and water'; and by live o'clock nest morning, got uider way to go out of the harbor'; soon saw the barge of the Dotterel lying under the frreen Islands, and said to the ofhers, we should be taken: the wind died away; we were becalmed, and the batre came down upen us and took us. 'The Reindeer, the Friend, and the Diligence being near, small lines were frassed from iny ressel to the Reindect and the Diligence, I being between them. When the barge came within, say one hundred rods. she fired over onr heads, and then a second time near us witlout speaking us: then came near and ordered the Reindeer to let go her anchor and all to cast apart: the anchor was let igo: then he went and boarded the liriend, which lay thirty or forty rods distant; then came again with their arms for action, and orderel us to cast apart. which was done: the reason we did not cast apart at first was, that we did not fally understand the order: then took possession of the Reintece. I then went on boand the licindecr; he then came and took possession of the Ruby. I asked why he towk me: and asked him if I was not allowed to go in for wool and water: he said I was: but it was time I was out: told him I had departed before I had ubtainerl as much as I wanter; I mentioned to him that the treaty allowed us to go in for wool and water: he said he did not care a dam for the treaty, every vessel he caught within three miles of the land he would make a prize of; he took out the crews and put iny cren on board the Diligence, and the Reindeer's crew on board thęf riend, and told the Friend and Diligence they might go: put a Midshipman and three men on board the Ribly, and directed them to follow him to St. Andrews, he being on board the Reindecr. We beat up round East Quoddy, and got up opposite Indian Island when the Diligence and Madison came upon us. Tle Diligence came upon the Ruby, having her own crew and five of ny crew, and two men from Eastport, twelve in all, on board, armed with muskets, and hailed us and told us to give up the ressel. I told the Midshipman I would go below, he asked me not to, said he would give up the vessel; he gave up the vessel; the Diligence took possession of her, and the Midshipman and his men went on board the barge. The Ruby was brought in; the crews of the risree vessels which were connected in 'I'wo Island harbor were never collected on board of my vessel. she being the midlle one, with muskets and fish spears; nor was there any such show of resistance made, or any such collection of men on board of cither vessel. When the vessels were retaken, there was not a gun fired till after they were both retaken, and then only by way of rejoicing. 'Tiney gave out that they would bave the Reindeer and Ruby if they had to burn Moose Island; I did not, therefore, think it prudent to trust her at sea again. 'The loss to the owner' and crew will be five hundred dollars.

ELISHA SMALL.

November 6th,1824.

Sworn to before E'THer SHeplex. 
I, Benjamin Small, on oath declare, that I was a hand on boart the schooner Ruby when she was taken by the Dotterel; that the statement of facts signed by Elisha Small has been read to me, and I know all the facts to be true which are related to have taken place before I came away in the Diligence. We came in the Diligence direct to Eastport; I went to Elisha D. Green, of Eastport, and told him I wanted ten muskets, it having been agreed between the Ruby's crew and the Diligence crew that we would retake the Ruby, he and another gentlenan obtained for us seven muskets; and the two clerks in Grecn's store, one named Iloward, and the other Fields, said they would go with us; they went on board with me; there being then twelve in all on board, having seven muskets, and two pistols, and two bayonets only, and went down behind dndian Island waiting fol them, laid there about half an hodl and satw the Madison coming lown; she spoke us, and Ficlds and Howard went on board the Madison, and khen l'cturned, having agreed that the Madison should at. tack the Reindecr, and the Diligence the Ruby; then all went below but three men; ran down and passed the Reindeer, and the Madisoin aptroached the Reindecr, and we the Ruby; I hailed the Ruby, and told her to heave to, being only three of us on deck; I hailed again and they did not obey: then the crew came up; then the men on board the Ruby let go the gib sheets and fetched her up into the wind; then our crew, and the two clerks, and James Leighton, Skiprer of the Diligence, went on board the Ruby and took possession of her: the men belonging to the barge left her and went on board the barge; we then hoisted American colors, discharged our muskets, and zan into Eastport; no muskets were fired till aiter the ressels were retaken. and the men belonging to the barge had left them.

November 6, 1824.

BENJAMIN SMALL。

Sworn to before Eruer SHeplex,

Benjanin W. Coggins, of Lubec, master of the schoune Ficul. of Lubec, on oath declares, that he sailed from Lubec, the anth of July last, and went on to the fishing giroud four or five leagues from Grand Menan. On the twenty-filth. secing Small, of the Redmeer, gring in, and vind blowing ficsh, and water short, followed him into 'f'vo ísland harbor", anchored there about four $0^{\circ} \mathrm{clock}, l^{\prime}$. M. went achore, and obtained whi.. water I could, and got it on boar! alwut nine same erening; wiml harl tlen died away; i coubl not get out; at five next moning a light brecze liom nonth west, got moler way, and went out in company with the lecindrel, Isuby, and biligence: wind ficel away. and rasel floated with thr current; barge

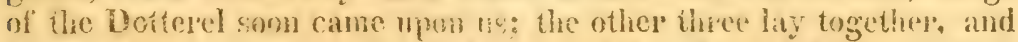
barge fuel oren them: direrefol one to let go her onchor, and then rame to me. acked me what hin, iness I had three. I told him I wa: 
becalmed, aril could not get out; he said that is a damned pretty answer to give me, when the wind was blowing here a gale all day resterday. I said yesterday I went to two Island harbor to obtain water. He then directed my sails to be hauled down and my anchor to be Iet go, which was done; he then left me, and directed the other ressers to cast apart: they did so, and cane to anchor: he boarded the Reindecr and took possession of her, and sent her crew on board of me, and they asked him, what if I would not take them? He told them to take my ressel then and go to Lubec. And I then took my brat, and went to sec Jones, and asked him if he was going to senil we to Lubec with the men? He said he was: and told me he would give me orders when I should get under way; in about half or three equarter's of an hour he gave me a signal to get under way. I did so, suid after getting out of sight, told the Reindeer's crew that if I could gin (ip) to lubec before they got up, would get some assistance there, whe go with tlic Friend and retake the Reindeer; came up as fast as bosid, and my reseel gromded before I got in; then hove out the hret, and Reindeer"s crew got into the boat with me and one of $\mathrm{my}$ ('Pre., and the Diligence towed us up to Lubec. Then went to the IDerne Cutter, Smith: told him the story, and asked him if he conld not go and re take them as they came in by East Quoddy? He said to conlt sot, but gave me a line to the collector: the collector refuseni ten tot the cutter go. Then went to the whart and hailed my brothr. who was master of the Madison, and asked him if he would let the In andison go and re-take the Reindeer, if I could obtain a crew; he srid he whili. I called round to get men to go on board; got four, snt? two rifhes and two muskets, and two pistols, and powder and hall took the men on board the Madison and went to Eastport; their, having seven men and four muskets, my brother having the command, wirn at Eastpor hatiled the men on the wharves, and asked them to send us two more mushets: they did send us two. and a man ran with them: thee run fown and spoke the Diligence. Mr. How-

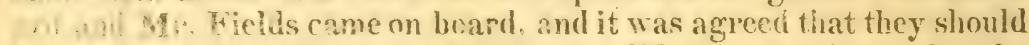
E. nill the Rriby, and me the Reindeer. We then ran down for the What . and liwy for the Ruby. We boarded the Reindeer first;

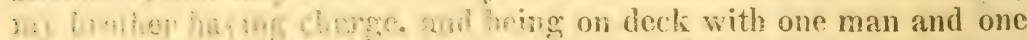

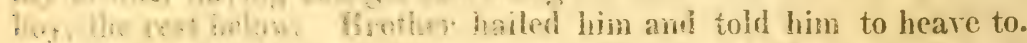
Bis anse mblent his men to griarters. Brother told him he would

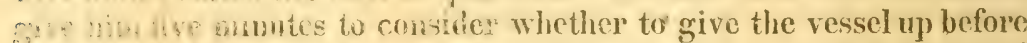

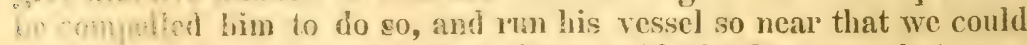
sien fonta one ressel to the other. Jones said, the first man that steps in hut on this ressin shall be at dearl man. Brother then called all bui from below: and we weat aip with our muskets, seven of us, there berng only ten men on board, besides two or three boys. Jones then lain his sword down and said the ressel is yours. We put four men on brati, and toll skipper. Small to make his way to Eastport. Jomes then vent on board his harge with his men. Then brother hailes him: aslied him to come on board the Madison and take armathing th drink, and he did. He then said we were good fellows 


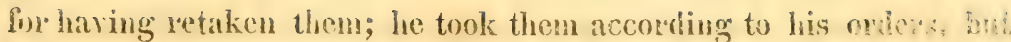
without aty provocation, and was glat we hat got then: he thers went his way, and we ous. 'There was no gun lines tilh after the

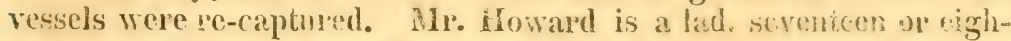
teen years ofd: has neser been a captain of any comprny of sulitia. I have hearit that he was captain of a company of boys in Eastoprt, who trained with wooten guns and swords.

On the twenty-nints of August last, being on Gand Menan Rank, saw the Dotreiel take possession of the l'ilgrim, she beigg then abont nine leagues distant from the Grand Menan. The Madison was also captured at the same time and place.

'The injury to me, by brealing up my fishing cruise, has been five hundred dollars.

Sworn to before

B. W. cOGGINS.

LTher Sinepley.

Nov. 6, 1824 .

IIenry Coggins, on oath, says, he has heard the statement signed by B. W. Coggins, read: is acruatinted with the whole transactions on board the friend, and knows them to be truly statel. Saw the Pilgrim and Madison taken the twenty-ninth of August, on the bank. nine leagues distant from the island.

Sworn to befole

IIENRY COGGINS.

Ether Sheptex.

Nov. 6, 1824.

November, 7 th, 1824.

1. Harding Clark, of Dennysville, master of the schooner Hero, of Dennysville, on oath, do testify and say, -.That I sailed on the thirteenth day of June last, fitted out for the fishery, and proceced on to Grand Menan bank, and continued to fish until the sixteenth; then struck adrift in the fore part of the day-made an atternpt to l'egain our ground, but not succeeding, the barge of the brig Dotterel came upon us, fired and boarded us-demanded our papers, which were given up, and took possession of the vessel, she being then from six to nine miles distant from the land.- Two of my men were taken out, and two of his put on board iny vessel, and I was directed to follow him.-I did follow and wait his movements for fourteen days, during which time he was employed in boarding vessels. - Was, during the time, in Beaver, and other harbors.-Often asked him to let me and my crew go home, there being opportunities, but was denied.-mone of the men being sick, was detained on board the barge, and did duty there, as did the other. At the expiration of the fourteen days, arrired at St. John's-were all there gut on board the Dotterel-were detained 
there two days, with on!y one meal of victuals, and then put on shore and dismisced.-Captain told me he had given the ressel up to Custom IIouse-went to the Custom House; was there told he had not.Asked if I could see the Captain again, and he was sent for, and he came-asked him to give up the vessel, telling him I did not consider her liable to seizure-he said he would think of it-said he wanted her fiol about a fortnight's cruise, and did not know but he should give her un to me then.-I returned home, and went there in a fortnight, as he desireal me. 'The Hero came in from a cruise three days after I arrived there, having been out cruising thirteen days.-She then took in supplies for another fortnight's cruise, and sailed again the same day, under the command of the pilot of the brig. Saw the Captain, and asked him if he would let me have the vessel, as he had agreed to-he said he had made a new arrangement, and should not let me have the vessel. I came home again and left her. When last at St. John's, I applied to Messr's. Crookshanks and Johnson, merchants of St. John's, to as.. certain when she was libelled or proceeded against; and about three weeks ago, received a letter from them, stating that the Hero had not been libelled; but had been employed as a tender to the Dotterel.The vessel was owned by Manning Clark and myself. The loss is not less than nine hundred dollars. I have not been out before this season-this being the first and only cruise this season.

HARDING CLARK.

\section{Sworn to before Erher Sheplex.}

6. William Rumery, of Lubec, testify and say, that I was a hand on board the schoonci Madison, of Lubec, fitted out for the fisheries; that we sailed about the 25th of August last, and went on to Grand Menan Bank about twenty-one miles or more from land, and fished till the 29th of the same month; saw a brig bearing down upon us; soon hailed us; asked the name of the vessel; Skipper not being then on board, I answered, the Madison; sent a boat aboard, and ordered all the crew aboard the boat, and carried us on board the brig Dotterel; ordered the Madison under way for Halifax; ordered us under the forecastle deck among the goats and fowls, where we remained four days; gave bread and water to us once a day; arrived fourth day at IIalifax. and set us all ashore but Robert Rumery; told us we must get a passage home as we could; we got a passage and came home, Jeaving the Madison at Halifax, where I suppose she is now. 'The fish and salt they sold out of her in harbor's on the way before they arrived in Halifax. The injury and loss is about nine hundred dollars. I saw Winslow in irons at Halifax.

WILLIAM RUMERY.

Norember 6th, 1824 .

Swoln to before

ETHER SHEPLEY. 
I, Robert Rumery, on oath, declare, that I have heard the statement signed by William Rumery read, and know that it is wholly true. I further state, that, after the remainder of the Madison's crew left us, I continued on board the Dotterel sixteen days; my brother William left me a little provision; after that was gone, I had nothing for two days; then had two-thirds of a seaman's ration, except grog; then got under way and came to L'Etau harbor, Dees Island; asked Lieutenant what he was going to do with me; said $I$ should be carried to St. Johns, and put in prison until my trial, and, no doubt, I should be hung; then got under way, and went to St. John's; laid there four days, then was told I might go on shore; went ashore and thence home.

I was a hand on board the Madison when she was going out and met the Diligence and Friend bringing in the crews of the Reindeer and Ruby that had been captured. After learning the facts, we put about and ran into Lubec and anchored. Benjamin Small wanted us to go with them and help take the Reindeer and Ruby, as the Friend had got aground, and Capt. Ansel Coggins, of the Madison, agreed to go, and all the crew but one, and took on board seven or eight others; there were not more than twelve or, at most, fifteen on board; had a number of muskets, but no bayonets; then went down upon the Reindeer; our Skipper hailed them, and told them to heave to; Jones told his men to prepare for action; we hailed a second time, and Jones ordered the fore sheet cast off, and told Robert Small that he might take charge of his vessel and carry her to Eastport. Jones and his men went aboard the barge, having first come on board of us and drank some grog by invitation, and we went to Eastport. No guns were fired till after the Reindeer was retaken, and Jones had left us and gone on board of his barge, and then only by way of rejoicing.

November 6th, 1824 .

ROBERT RUMERY.

Sworn to before

ETHER SHEPLEY.

DR. The United States to Ether Shepley.

1824.

Nov. 16. To services making inquiry relating to the difliculties between our fishermen, and the officers of the British armed brig Dotterel; travelled 540 miles; took twenty-seven depositions; $a b$ sent nineteen days, and expenses, - \$\$25000 Received payment, 
CoLumвi, September 27, 1824.

SIn: Enclosed is a regular protest, in relation to the capture of the schooner Rebecca, which case, with others, it is hoped, will receive the attention of Government.

Respectfully, your obedient servant,

Hon. John Quincy Adams, STEPHEN EMERY.

Secretary of State.

\section{United States of America.}

\section{$\left.\begin{array}{c}\text { State of Maine, } \\ \text { Washington, }\end{array}\right\}$ ss.}

Be it known that on the twelfth day of July, in the year of our Lord one thousand eight hundred and twenty-four, personally appeared before me, Solomon Thayer, Notary Public, by legal authority duly admitted and sworn, and dwelling at Lubec, state and county aforesaid, Jones Wass, master of the schooner Rebecca, of Addison, and noted his protest. And now, on this ninth day of September, A. D. 1824, he again appears to extend the same; and with him, also appears John Wright, fisherman, belonging to the said schooner, who, being severally sworn, do depose and say, that, on the twenty-ninth day of June, now last past, they sailed in said schooner Rebecca from Addison, on a fishing cruize on the Grand Menan Banks, and arrived there on Thursday, the first day of July, and commenced fishing at a distance of fifteen miles from land-continued to fish during that day. On the next night, the wind springing up quite fresh, were obliged to run in to Grand Menan for a harbur. Arrived at Duck Island, so called, and anchored at two o'clock Friday morning; went on shore, and obtained a barrel of water, having a half barrel only on board. In about an hour from the time of anchoring, saw an armed boat making towards us; up anchor and stood to sea. The armed boat gave chace, and continued it all the next day, frequently firing muskets at the schooner Rebecca. As soon as it came on dark she lost sight of us, we were then near the Nova Scotia shore. We then put back to Grand Menan, and arrived there the next morning. Immediately made for the fishing banks, and continued to fish there that day. At night, the wind blowing quite fresh, run in for a harbor. The next day, being the fourth of July, and Sunday, went on to the banks and anchored; the next morning commenced fishing, and caught twenty quintals. 'The following night, wind fresh, hove up, and laid to under our foresail until morning; then run into Bucks rock, so called, near Grand Menan, to procure wood, and to dress our fish. In about half an hour after we arrived, the same boat that had chased us on Friday, came upon us, and took forcible possession of the Re- 
becca, and her papers, ordered her underweigh, and took her to the city of St. John's, and stripped her.

The declarants further say, that during said cruize, they did not fish within from twelve to fifteen miles from Grand Menan, nor run in near the land, unless to get water, purchase wood, and from stress of weather.

The said Jones Wass, for himself, saith, that, on the seventh day of September, now current, he left the city of St. John's, where he had been to solicit the liberation of the said schooner Rebecca, but that said schooner had not then been libelled for trial, and that he was told by Charles J. Peters, the Judge of the Vice Admiraity Courts for the Province of New Brunswick, it was uncertain when she wonld be.

Wherefore, they do protest, and I, the said Notary, in their behalf, do solemnly protest, against said armed boat, against pirates, and the wanton abuse of power by armed boats on the high seas, under pretence of authority; against being deprived of rights, confirmed to American fishermen by the convention -with Great Britain of 1818, and against winds, seas, and tides, and whatsoever else may have caused the capture, and wanton detention, of the said schooner Rebecca, of Addison. JOHN WRIGHT.

In faith whereof, I have hereunto anfixed my seal, and subscribed my name, the ninth day of September, A. D.

[SEAL.] eighteen hundred and twenty-four. SOLOMON THAYER. Notary Public. 


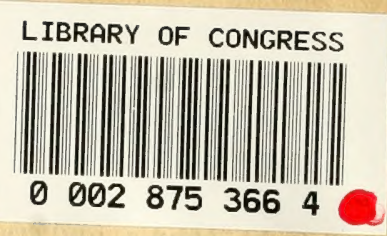

